This is an electronic reprint of the original article. This reprint may differ from the original in pagination and typographic detail.

Author(s): Kuosmanen, Riikka; Puttreddy, Rakesh; Willman, Roosa-Maria; Äijäläinen, Ilkka; Galandáková, Adéla; Ulrichová, Jitka; Salo, Hannu; Rissanen, Kari; Sievänen, Elina

Title: $\quad$ Biocompatible Hydrogelators Based on Bile Acid Ethyl Amides

Year: $\quad 2016$

Version:

Please cite the original version:

Kuosmanen, R., Puttreddy, R., Willman, R.-M., Äijäläinen, I., Galandáková, A., Ulrichová, J., Salo, H., Rissanen, K., \& Sievänen, E. (2016). Biocompatible Hydrogelators Based on Bile Acid Ethyl Amides. Steroids, 108, 7-16.

https://doi.org/10.1016/j.steroids.2016.02.014

All material supplied via JYX is protected by copyright and other intellectual property rights, and duplication or sale of all or part of any of the repository collections is not permitted, except that material may be duplicated by you for your research use or educational purposes in electronic or print form. You must obtain permission for any other use. Electronic or print copies may not be offered, whether for sale or otherwise to anyone who is not an authorised user. 


\section{Accepted Manuscript}

Biocompatible Hydrogelators Based on Bile Acid Ethyl Amides

Riikka Kuosmanen, Rakesh Puttreddy, Roosa-Maria Willman, Ilkka Äijäläinen, Adéla Galandáková, Jitka Ulrichová, Hannu Salo, Kari Rissanen, Elina Sievänen

PII: S0039-128X(16)00045-3

DOI: http://dx.doi.org/10.1016/j.steroids.2016.02.014

Reference: STE 7931

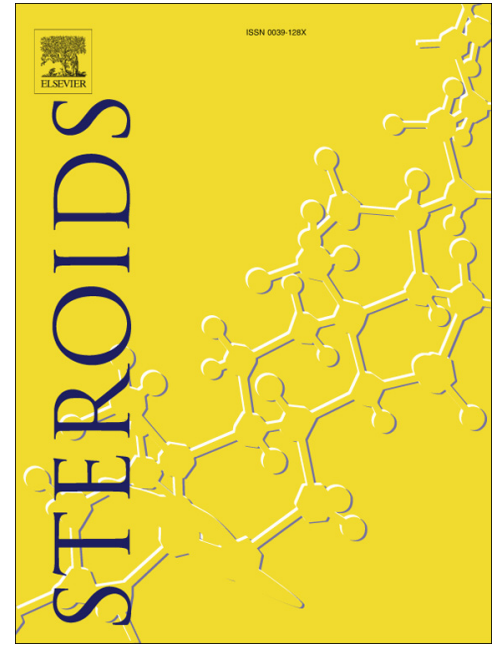

To appear in: $\quad$ Steroids

Received Date: $\quad 1$ December 2015

Revised Date: $\quad 15$ February 2016

Accepted Date: $\quad 18$ February 2016

Please cite this article as: Kuosmanen, R., Puttreddy, R., Willman, R-M., Äijäläinen, I., Galandáková, A., Ulrichová, J., Salo, H., Rissanen, K., Sievänen, E., Biocompatible Hydrogelators Based on Bile Acid Ethyl Amides, Steroids (2016), doi: http://dx.doi.org/10.1016/j.steroids.2016.02.014

This is a PDF file of an unedited manuscript that has been accepted for publication. As a service to our customers we are providing this early version of the manuscript. The manuscript will undergo copyediting, typesetting, and review of the resulting proof before it is published in its final form. Please note that during the production process errors may be discovered which could affect the content, and all legal disclaimers that apply to the journal pertain. 


\title{
Biocompatible Hydrogelators Based on Bile Acid Ethyl Amides
}

\author{
Riikka Kuosmanen, Rakesh Puttreddy, Roosa-Maria Willman, Ilkka Äijäläinen, Adéla \\ Galandáková, Jitka Ulrichová, Hannu Salo, Kari Rissanen, and Elina Sievänen* \\ University of Jyvaskyla, Department of Chemistry, P.O.Box 35, FI-40014 University of Jyvaskyla,
}

Finland

\begin{abstract}
Four novel bile acid ethyl amides were synthetized using a well-known method. All the four compounds were characterized by IR, SEM, and X-ray crystal analyses. In addition, the cytotoxicity of the compounds was tested. Two of the prepared compounds formed organogels. Lithocholic acid derivative 1 formed hydrogels as $1 \%$ and $2 \%(\mathrm{w} / \mathrm{v})$ in four different aqueous solutions. This is very intriguing regarding possible uses in biomedicine.
\end{abstract}

Keywords: Bile acid, Amide, Self-assembly, Supramolecular hydrogel, Biocompatibility

\section{Introduction}

Bile acids are a fascinating group of biologically important molecules belonging to the group of steroids. ${ }^{1,2}$ Because of their relatively low cost, wide availability, and enantiomeric purity, bile acids are ideal building blocks for gelator molecules. The structure of the bile acids consists of a steroidal backbone and an aliphatic side chain. ${ }^{3}$ The facially amphiphatic nature of bile acids arises from their concave hydrophilic face and convex hydrophobic face. Chemically different hydroxyl groups in the concave face and the varying amount of them, as well as the rigid steroidal backbone, are important with regard to bile acids' biological etc. properties. Because bile acids are endogenous compounds ${ }^{4}$, they are perfect starting materials for biological and medical applications. ${ }^{3,5}$

Bile acids and their derivatives have various applications especially in biomedicine. There are multiple examples in the field of cancer treatment. ${ }^{6-11}$ One particularly interesting potential application involves mixing of sodium deoxycholate solutions to Au-nanoparticle (AuNP) solution to create multiple-branched Au-NPs. ${ }^{8}$ AuNPs formed have such a strong NIR absorption that they 
can be used to destroy tumor cells. Many examples include bile acid based compounds as drug carriers $^{12-17}$, and even gene ${ }^{18,19}$ or RNA $^{20}$ carriers. Majority of potential applications of bile acids, or their derivatives, as drug carriers utilize bile acid transportation systems present in organisms/humans to achieve site-specific action of the drug carried. In addition, bile acid derivatives have shown potential as drug absorption modifiers. ${ }^{21,22}$

Gels play increasingly important roles in modern life since they appear in myriad of applications ranging from optoelectronics ${ }^{23,24}$ and biomedicine ${ }^{23-25}$ to environmental clean-up. ${ }^{26,27}$ Universally a gel is defined as a viscoelastic solid like material which consists of flexible cross-linked network and solvent. Gelator molecules form the cross-linked 3D network that attracts and captures solvent molecules. Gels are divided into different classes based on the solvent used. In hydrogels the solvent is pure water or water solution. If the solvent is organic, the gel is called an organogel, and dried gels are categorized as xerogels.

In the field of supramolecular gels the research focuses mainly on low molecular weight gelators (LMWG). ${ }^{28}$ Typically LMWGs form gel networks that resemble fibres. LMWGs consist of a rich variety of molecules to which bile acids and their derivatives enter into.

The first examples of bile acid salts forming hydrogels were reported in the early 20th century. ${ }^{29-31}$ Despite of that there is a limited amount of bile acid salts and derivatives known to function as hydrogelators. Most of the bile acid based hydrogels reported have been discovered by Maitra and his co-workers. Maitra's research group has reported intriguing gel systems, including cholic acid based luminescent europium containing gels and tripodal cholamide supergelator. This is, however, the first time bile acid alkyl amide derivatives are reported to gelate aqueous solutions.

Gels have potential use in biological applications only if they form in biocompatible solvents. Supramolecular hydrogels are considered to be biologically compatible, moreover they are formed in many cases by naturally occurring molecules which are most likely to be nontoxic. ${ }^{32}$ Bile acid based hydrogels are considered to be fully biologically compatible when the gelator molecule itself is not toxic. The full biocompatibility of a hydrogel provides perhaps new potential applications regarding biomedicine, such as drug delivery, artificial tissue engineering, etc.

In relation to the previous work done by our research group ${ }^{33-40}$, in this work we have focused on how the compounds we have prepared behave in aqueous media. As a continuation of the series of bile acid alkyl or functionalized alkyl amide/ester derivatives capable of acting as gelators we report 
four new bile acid ethyl amide based gelator molecules, which have shown potential in forming hydrogels.

\section{Experimental}

\subsection{Materials}

Lithocholic acid ( $\geq 97 \%)$, deoxycholic acid ( $\geq 99 \%)$, cholic acid ( $\geq 97 \%)$, and dehydrocholic acid $(\geq 99.0 \%)$ were purchased from Sigma. Ethyl amide hydrochloride was purchased from Fluka. Triethyl amide, ethyl chloroformate, and other reagents used during the synthesis as well as solvents used in chromatography and gelation studies were of analytical grade. Ethyl chloroformate was distilled and 1,4-dioxane was dried over Na prior to use. All other chemicals were used without further purification. The synthetic route to 1-4 is presented in Scheme 1. The mixed anhydride method used has been previously reported by our research group. ${ }^{41}$

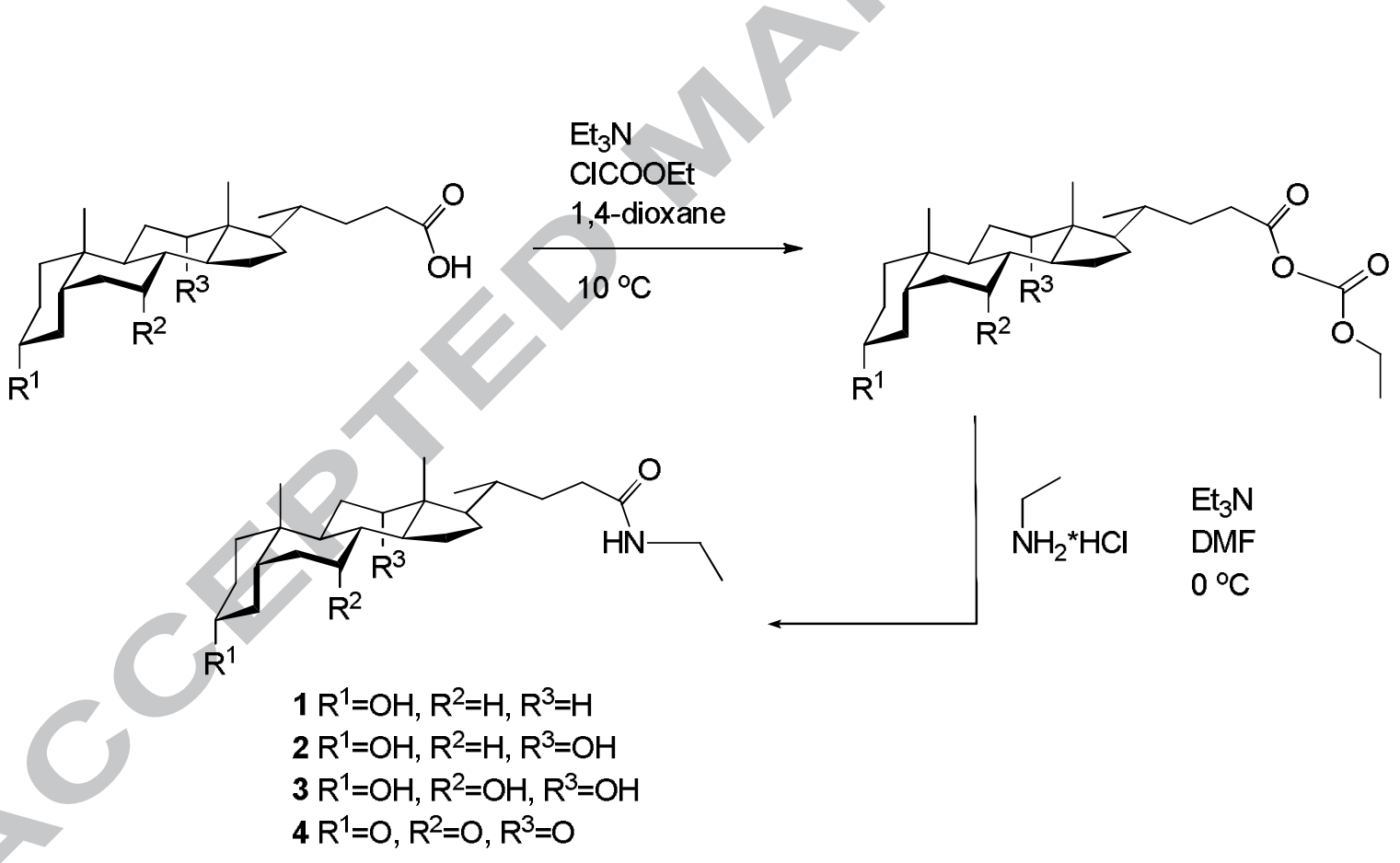

Scheme 1: The synthetic route leading to compounds $\mathbf{1}-\mathbf{4}$. 
2.2 General procedure for the synthesis of the bile acid ethyl amide conjugates 1-4

Reactions were performed under $\mathrm{N}_{2}$ atmosphere. In a round-bottomed three-necked flask bile acid ( 5 mmol, 1 eq.) and 1,4-dioxane (42 mL) were cooled on an ice-water bath to $+10^{\circ} \mathrm{C}$. To the cooled solution triethyl amide (6.7 mmol, 1.34 eq.) was added from a dropping funnel, followed by a dropwise addition of ethyl chloroformate $(6.7 \mathrm{mmol}, 1.34$ eq.) in 1,4-dioxane $(3 \mathrm{~mL})$. The mixture was stirred at $\mathrm{rt}$ for $30 \mathrm{~min}$. Meanwhile in another flask ethyl amide hydrochloride (6.7 mmol, 1.34 eq.) was suspended in DMF (10 mL). Suspension was cooled on ice-salt bath to $0{ }^{\circ} \mathrm{C}$ after which triethyl amide (7.4 mmol, 1.48 eq.) was added from a dropping funnel. The mixture was stirred at $\mathrm{rt}$ for 30 min. Ethyl amide in DMF was added dropwise to the bile acid anhydride and stirring of the reaction mixture continued at $\mathrm{rt}$ for $20 \mathrm{~h}$. Volatiles were evaporated and the crude product was dissolved in $\mathrm{CHCl}_{3}(100 \mathrm{~mL})$. The crude product was washed with water $(2 \times 75 \mathrm{~mL}), 0.1 \mathrm{M} \mathrm{HCl}$ solution $(2 \times 75 \mathrm{~mL})$, water $(2 \times 75 \mathrm{~mL})$, and brine $(2 \times 75 \mathrm{~mL})$. The organic layer was dried $\left(\mathrm{Na}_{2} \mathrm{SO}_{4}\right)$, filtered, and the volatiles evaporated under reduced pressure. The crude products were purified by column chromatography (silica gel, DCM:MeOH 96:4 for 1, 90:10 for 2, x:y for 4, and $\mathrm{CHCl}_{3}: \mathrm{MeOH} 86: 14$ for 3). All pure products were dried under vacuum.

2.2.1 Lithocholic acid ethyl amide $\mathbf{1}$

Yield $57 \%$. ${ }^{1} \mathrm{H}$ NMR $\left(\mathrm{CDCl}_{3}, 500 \mathrm{MHz}, \mathrm{ppm}\right): \delta 5.44(\mathrm{t}, 1 \mathrm{H}, \mathrm{NH}), 3.62(\mathrm{~m}, 1 \mathrm{H}, 3 \beta-$ $\mathrm{H}), 3.28\left(\mathrm{~m}, 2 \mathrm{H}, 25-\mathrm{CH}_{2}\right), 2.21 / 2.04\left(\mathrm{~m}, 2 \mathrm{H}, 23-\mathrm{CH}_{2}\right), 1.14\left(\mathrm{t}, 3 \mathrm{H}, 26-\mathrm{CH}_{3}\right), 0.91\left(\mathrm{~d}, 3 \mathrm{H}, 21-\mathrm{CH}_{3}\right)$, $0.91\left(\mathrm{~s}, 3 \mathrm{H}, 19-\mathrm{CH}_{3}\right), 0.64\left(\mathrm{~s}, 3 \mathrm{H}, 18-\mathrm{CH}_{3}\right) .{ }^{13} \mathrm{C} \mathrm{NMR}\left(\mathrm{CDCl}_{3}, 126 \mathrm{MHz}, \mathrm{ppm}\right): \delta 173.4(\mathrm{C}-24)$, 71.8 (C-3), 56.5 (C-14), 56.1 (C-17), 42.8 (C-13), 42.1 (C-5), 40.5 (C-9), 40.2 (C-12), 36.5 (C-4), 35.9 (C-8), 35.5 (C-20), 35.4 (C-1), 34.6 (C-10), 34.3 (C-25), 33.7 (C-23), 31.8 (C-22), 30.6 (C-2), 28.2 (C-16), 27.2 (C-6), 26.4 (C-4), 24.2 (C-15), 23.4 (C-21), 20.8 (C-7), 18.4 (C-19), 14.9 (C-26), $12.0(\mathrm{C}-18)$. MS: $m / z 426.7[\mathrm{M}+\mathrm{Na}]^{+}, 830.5[2 \mathrm{M}+\mathrm{Na}]^{+}$.

\subsubsection{Deoxycholic acid ethyl amide 2}

Yield $75 \%$. ${ }^{1} \mathrm{H} \mathrm{NMR}\left(\mathrm{CDCl}_{3}, 500 \mathrm{MHz}, \mathrm{ppm}\right): \delta 5.50(\mathrm{t}, 1 \mathrm{H}, \mathrm{NH}), 3.97$ (m, 1H, $12 \beta-$ H), $3.61(\mathrm{~m}, 1 \mathrm{H}, 3 \beta-\mathrm{H}), 3.28\left(\mathrm{~m}, 2 \mathrm{H}, 25-\mathrm{CH}_{2}\right), 2.23 / 2.06\left(\mathrm{~m}, 2 \mathrm{H}, 23-\mathrm{CH}_{2}\right), 0.97$ (d, 3H, 21- $\left.\mathrm{CH}_{3}\right)$, $0.90\left(\mathrm{~s}, 3 \mathrm{H}, 19-\mathrm{CH}_{3}\right), 0.65$ (s, 3H, 18- $\left.\mathrm{CH}_{3}\right) .{ }^{13} \mathrm{C} \mathrm{NMR}\left(\mathrm{CDCl}_{3}, 126 \mathrm{MHz}, \mathrm{ppm}\right): \delta 173.4(\mathrm{C}-24)$, 73.2 (C-12), 71.8 (C-3), 48.3 (C-14), 47.2 (C-17), 46.5 (C-13), 42.1 (C-5), 36.4 (C-4), 36.0 (C-8), 
35.2 (C-1, C-20), 34.4 (C-25), 34.1 (C-10), 33.7 (C-9), 33.5 (C-23), 31.7 (C-22), 30.5 (C-2), 28.7 (C-11), 27.5 (C-16), 27.1 (C-6), 26.1 (C-7), 23.7 (C-15), 23.2 (C-19), 17.5 (C-21), 14.9 (C-26), 12.8 (C-18). MS: $m / z 442.7[\mathrm{M}+\mathrm{Na}]^{+}, 862.5[2 \mathrm{M}+\mathrm{Na}]^{+}$.

\subsubsection{Cholic acid ethyl amide $\mathbf{3}$}

Yield $53 \% .{ }^{1} \mathrm{H}$ NMR $\left(\mathrm{CDCl}_{3}, 500 \mathrm{MHz}, \mathrm{ppm}\right): \delta 5.76(\mathrm{t}, 1 \mathrm{H}, \mathrm{NH}), 3.96(\mathrm{~m}, 1 \mathrm{H}, 12 \beta-$ H), $3.84(\mathrm{~m}, 1 \mathrm{H}, 7 \beta-\mathrm{H}), 3.44(\mathrm{~m}, 1 \mathrm{H}, 3 \beta-\mathrm{H}), 3.27\left(\mathrm{~m}, 2 \mathrm{H}, 25-\mathrm{CH}_{2}\right), 2.21 / 2.09\left(\mathrm{~m}, 2 \mathrm{H}, 23-\mathrm{CH}_{2}\right)$, 0.99 (d, 3H, 21- $\left.\mathrm{CH}_{3}\right), 0.88\left(\mathrm{~s}, 3 \mathrm{H}, 19-\mathrm{CH}_{3}\right), 0.68\left(\mathrm{~s}, 3 \mathrm{H}, 18-\mathrm{CH}_{3}\right) .{ }^{13} \mathrm{C} \mathrm{NMR}\left(\mathrm{CDCl}_{3}, 126 \mathrm{MHz}\right.$, ppm): $\delta 173.6$ (C-24), 73.1 (C-12), 72.0 (C-3), 68.4 (C-7), 46.8 (C-17), 46.5 (C-13), 41.9 (C-14), 41.5 (C-5), 39.7 (C-4), 39.6 (C-8), 35.3 (C-1, C-20), 34.7 (C-6, C-10), 34.4 (C-23), 33.3 (C-25), 31.7 (C-22), 30.6 (C-2), 28.3 (C-11), 27.5 (C-16), 26.6 (C-9), 23.2 (C-15), 22.5 (C-19), 17.5 (C-21), $14.9(\mathrm{C}-26), 12.6(\mathrm{C}-18)$. MS: $m / z, 458.8[\mathrm{M}+\mathrm{Na}]^{+}, 474.8[\mathrm{M}+\mathrm{K}]^{+}, 894.6[2 \mathrm{M}+\mathrm{Na}]^{+}$.

2.2.4 Dehydrocholic acid ethyl amide 4

Yield $34 \% .{ }^{1} \mathrm{H}$ NMR $\left(\mathrm{CDCl}_{3}, 500 \mathrm{MHz}, \mathrm{ppm}\right): \delta 5.50(\mathrm{t}, 1 \mathrm{H}, \mathrm{NH}), 3.27$ (m, 2H, 25$\left.\mathrm{CH}_{2}\right), 2.88(\mathrm{~m}, 1 \mathrm{H}, 8-\mathrm{CH}), 1.39$ (t, 3H, 26- $\left.\mathrm{CH}_{3}\right), 1.12\left(\mathrm{~d}, 3 \mathrm{H}, 21-\mathrm{CH}_{3}\right), 1.06\left(\mathrm{~s}, 3 \mathrm{H}, 19-\mathrm{CH}_{3}\right), 0.84$ (s, 3H, 18- $\left.\mathrm{CH}_{3}\right) .{ }^{13} \mathrm{C} \mathrm{NMR}\left(\mathrm{CDCl}_{3}, 126 \mathrm{MHz}, \mathrm{ppm}\right): \delta 211.9$ (C-12), 208.9 (C-3), 208.6 (C-7), 173.1 (C-24), 56.9 (C-13), 51.8 (C-14), 48.9 (C-8), 46.8 (C-5), 45.6 (C-17), 45.5 (C-9), 44.9 (C-6), 42.8 (C-4), 38.6 (C-11), 36.4 (C-2), 35.9 (C-10), 35.5 (C-20), 35.2 (C-1), 34.3 (C-25), 33.6 (C-23), 31.2 (C-22), 27.6 (C-15/C-16), 25.1 (C-15/C-16), 21.9 (C-26), 18.7 (C-18), 14.9 (C-21), 11.8 (C-19). MS: $m / z 452.7[\mathrm{M}+\mathrm{Na}]^{+}, 484.8[\mathrm{M}+\mathrm{MeOH}+\mathrm{Na}]^{+}$.

\subsection{NMR spectroscopy}

${ }^{1} \mathrm{H},{ }^{13} \mathrm{C}$, and $2 \mathrm{D}{ }^{1} \mathrm{H},{ }^{13} \mathrm{C}$ HMQC and HMBC spectra used for characterization of the compounds $\mathbf{1}-\mathbf{4}$ were recorded with a Bruker Avance DRX $500 \mathrm{MHz}$ spectrometer. The spectrometer was equipped with $5 \mathrm{~mm}$ diameter broad band inverse detection probehead operating at $500.17 \mathrm{MHz}$ in ${ }^{1} \mathrm{H}$ and 125.77 MHz in ${ }^{13} \mathrm{C}$ experiments, respectively. The ${ }^{1} \mathrm{H}$ NMR chemical shifts are referenced to the signal of residual $\mathrm{CHCl}_{3}$ (7.26 ppm from internal TMS). The ${ }^{13} \mathrm{C} \mathrm{NMR}$ chemical shifts are 
referenced to the centre peak of the solvent $\mathrm{CDCl}_{3}$ (77.0 ppm from internal TMS). A composite pulse decoupling, Waltz-16, has been used to remove proton couplings from ${ }^{13} \mathrm{C}$ NMR spectra.

\subsection{Mass spectrometry}

Compounds 1-4 were studied by mass spectrometry. Measurements were performed by using Micromass LCT time of flight (TOF) mass spectrometer with electrospray ionization (ESI). Measurements were conducted using positive ion mode. MassLynx NT software system was used to control the spectrometer, and to acquire and process the data. Flow rate for the sample solutions was $10 \mu \mathrm{L} / \mathrm{min}$. Sample cone and extraction cone potentials were $40 \mathrm{~V}$ and $6 \mathrm{~V}$, respectively. The capillar cone potential varied between $3600 \mathrm{~V}$ and $4000 \mathrm{~V}$, RF lens potential was $250 \mathrm{~V}$ in all measurements. The desolvation temperature was set to $120^{\circ} \mathrm{C}$ and the source temperature to $80{ }^{\circ} \mathrm{C}$.

Stock solutions of compounds 1-4 were $1 \mathrm{mM}$ in acetone. Measurement solutions were prepared from stock solutions by diluting them to $10 \mu \mathrm{M}$ or $20 \mu \mathrm{M}$ in methanol.

\subsection{IR-spectroscopy}

Compounds 1-4 were studied by IR-spectroscopy. Measurements were conducted using Bruker Tensor 27 Fourier transform IR-spectrometer equipped with GladiATR ${ }^{\mathrm{TM}}$ accessory in the range of 400-4000 $\mathrm{cm}^{-1}$. Compounds $\mathbf{1}-\mathbf{4}$ were measured in solid state. Hydrogels formed by compound $\mathbf{1}$ in $2 \%$ (w/v) in 50:50 $\mathrm{H}_{2} \mathrm{O}: 2$-propanol, and 10:90 $\mathrm{H}_{2} \mathrm{O}$ :acetone and $\mathrm{H}_{2} \mathrm{O}$ :acetonitrile were also studied. For the measurements of the hydrogels of compound 1, the solution system in question was measured and the spectrum obtained was subtracted from the spectrum of the gel to eliminate the background signal.

\subsection{Gelation studies}

Self-assembly properties of compounds $1-\mathbf{4}$ were studied by weighing $5 \mathrm{mg}$ to obtain $1 \%(\mathrm{w} / \mathrm{v})$ systems or $10 \mathrm{mg}$ to obtain $2 \%(\mathrm{w} / \mathrm{v})$ systems of a particular compound in a test tube and adding $500 \mu \mathrm{l}$ of solvent or solvent mixture in question. The mixture was subjected to ultrasound for ca. 1 min with the cap on and heated with a heat gun until the compound was dissolved or the boiling point of the solvent reached without the cap. The solution or suspension was cooled to $\mathrm{rt}$ and the 
observations with regard gelation were made within 1-2 $\mathrm{h}$ after cooling had commenced. Formed solid mass was defined as a gel if there was no solvent flow when test tube was inverted. Possible crystallization and precipitation was observed within days or weeks. Test tubes were stored at $\mathrm{rt}$ during the observation time.

\subsection{SEM}

Samples for SEM were prepared by a traditional method. The hot solution containing the gelator in question in an appropriate solvent system was pipetted to the sample stub, and the gel allowed to form while cooling to room temperature. In addition to the traditional method, samples were prepared also directly from previously formed gels. A small amount of a gel in question was scooped with a spatula and the sample stub was thinly brushed with the gel. The gel was allowed to dry on the sample stub in both methods of sample preparation. After drying, all samples were thinly plated with gold with JOEL Fine Coat Ion Sputter JFC-1100. Micrographs were taken with Bruker Quantax400 EDS scanning electron microscope equipped with a digital camera.

\subsection{Toxicity evaluation}

\subsubsection{Cell culture}

Mouse fibroblasts Balb/c 3T3 (No. 86110401) was obtained from European Collection of Cell Cultures (UK). Cell line stored in a cryovial were taken out of the liquid nitrogen and thawed in water $\left(25^{\circ} \mathrm{C}\right.$; $\left.1 \mathrm{~min}\right)$. Using a pipette, cells were transferred into a $25 \mathrm{~cm}^{2}$ tissue culture flask containing $10 \mathrm{ml}$ of pre-heated culture medium (DMEM, penicillin $100 \mathrm{U} / \mathrm{ml}$, L-glutamine $2 \mathrm{mmol} / \mathrm{l}$, streptomycin $100 \mathrm{mg} / \mathrm{l}$, fetal calf serum 5\%, new born calf serum 5\%) and incubated in humidified atmosphere with $5 \%(\mathrm{v} / \mathrm{v}) \mathrm{CO}_{2}$ at $37^{\circ} \mathrm{C}$. The medium was changed every 24-48 h. Cells were cultivated to approach confluence and were passaged. The medium was replaced and cells were washed with PBS $(5 \mathrm{ml})$. Solution was removed and $0.25 \%$ trypsin-EDTA was added $(0.5 \mathrm{ml}, 2$ $\left.3 \mathrm{~min}, 37^{\circ} \mathrm{C}\right)$. Then $5 \mathrm{ml}$ of culture medium was applied, cells were centrifuged (10 min; $1300 \mathrm{rpm}$; RT) and the supernatant was removed. The cell pellet was resuspended in $20 \mathrm{ml}$ of culture medium and suspension was transferred to the $75 \mathrm{~cm}^{2}$ cultivating flask. During cultivating in a $75 \mathrm{~cm}^{2}$ tissue culture flask the procedure was the same, only $10 \mathrm{ml}$ of PBS, $1 \mathrm{ml}$ of trypsin-EDTA and $10 \mathrm{ml}$ of culture medium were used. 


\subsubsection{Sample preparation}

Stock solutions of samples 1 and $2(0.039-5 \mathrm{mg} / \mathrm{ml})$ and 3 and $4(0.156-20 \mathrm{mg} / \mathrm{ml})$ were prepared in DMSO. The final concentration of DMSO in serum-free medium was $0.5 \%(\mathrm{v} / \mathrm{v})$. The DMSO was added to the compounds, thoroughly mixed $(2 \mathrm{~min})$, and sonicated $(10 \mathrm{~min})$. Control cells were incubated with a corresponding volume of DMSO.

\subsubsection{Procedure}

The concentrations of the cells were determined using coloured with trypan blue. The cells were seeded in 96-well plates at a density of $0.8 \times 10^{5}$ cells $/ \mathrm{ml}(200 \mu \mathrm{l} /$ well $)$ in culture medium and incubated for $24 \mathrm{~h}$ in a humidified atmosphere $\left(37^{\circ} \mathrm{C}, 5 \% \mathrm{CO}_{2}\right)$. Then the culture medium was change to the serum-free one containing test compounds in concentration ranges of $0.195-25 \mu \mathrm{g} / \mathrm{ml}$ for 1 and 2, and $0.781-100 \mu \mathrm{g} / \mathrm{ml}$ for 3 and 4, and incubated for $24 \mathrm{~h}\left(37^{\circ} \mathrm{C}, 5 \% \mathrm{CO}_{2}\right)$. After incubation period the cell damage was evaluated as the incorporation of neutral red into the lysosomes of living cells (Neutral red assay). The test was performed in 3 independent experiments.

\subsubsection{Neutral red assay}

The neutral red (NR) assay is grounded on the fact that live (non-damaged) cells intake and store NR into their lysosomes. The concentration of the incorporated dye is determined spectrophotometrically at $540 \mathrm{~nm}$ after extraction of retained NR into acidic methanolic solution. ${ }^{42}$

After the incubation period the cells were first washed with PBS, and subsequently NR solution $(0.03 \%$, w/v in PBS $)$ was applied to the cells for $3 \mathrm{~h}\left(37{ }^{\circ} \mathrm{C}, 5 \% \mathrm{CO}_{2}\right)$. Then the cells were washed with a washing solution (formaldehyde $\left(0.125 \%\right.$; v/v), $\mathrm{CaCl}_{2}(0.25 \%$, w/v)), and the retained NR was dissolved in extraction solution (methanol (50\%; v/v), acetic acid (1\%; v/v)). The absorbance was measured with a microplate reader (Sunrise Remote, Tecan, Austria). 


\subsection{X-ray crystallography}

Single crystal X-ray data for $\mathbf{1 , 2}$, and $\mathbf{3}$ were collected at either 120 or $123 \mathrm{~K}$ using Agilent SuperNova dual source wavelength diffractometer with an Atlas CCD detector using multilayer optics monochromatized $\mathrm{CuK}_{\alpha}(\lambda=1.54184 \AA)$ radiation. The data collection and reduction for $\mathbf{1}, \mathbf{2}$, and $\mathbf{3}$ was performed using the program CrysAlisPro. ${ }^{43}$ Gaussian face index absorption correction method $^{43}$ was used for 1, 2, and 3. All the structures were solved with direct methods $(\text { SHELXS })^{44}$ and refined by full-matrix least squares on $F^{2}$ using the $O L E X 2^{45}$, which utilizes the SHELXL-2013 module. ${ }^{44}$ No attempt was made to locate the hydrogens for solvent molecules and heteroatoms, and all the hydrogen atoms were added using ADD $\mathrm{H}$ command in OLEX2. Attempts to solve the disorder of $\mathrm{N}$-ethyl chain in compound 3 still engenders $\mathrm{B}$-alerts and requires the usage of constraints (EADP) and restraints (ISOR), which ultimately affects the $\mathrm{R}_{1}$-value significantly. As a result, considering the conformational importance of side chain during our discussion, no attempt was made to solve the disorder.

\section{Results and discussion}

\subsection{Synthesis}

A well-established method, employed several times by our research group ${ }^{41,46}$, was used to synthesize compounds 1-4. Syntheses were relatively fast compared to syntheses that last several days ${ }^{46}$. Purification of compounds $\mathbf{3}$ and $\mathbf{4}$ was challenging, probably due to the three hydrophilic functional groups of the steroidal backbone which cause stronger interactions with silica gel when using column chromatography. Yields varied between 34-75\%.

\subsection{Gelation studies}

Gelation properties of compounds 1-4 (figure 1) were tested in 28 solvents at $1 \%(\mathrm{w} / \mathrm{v})$ and in various aqueous solutions at $1 \%$ and $2 \%(\mathrm{w} / \mathrm{v})$ concentration. The results obtained are summarized in Tables 1 and 2, respectively. 


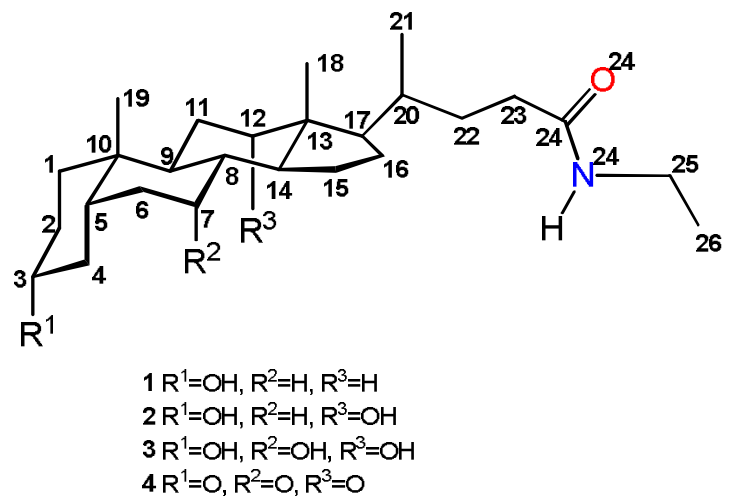

Figure 1: Chemical structures of compounds 1-4.

Table 1: Gelation test results for compounds 1-4 at $1 \%(\mathrm{w} / \mathrm{v})$ concentration.

\begin{tabular}{|c|c|c|c|c|}
\hline Solvent & 1 & 2 & 3 & 4 \\
\hline $\mathrm{CHCl}_{3}$ & $\mathrm{~S}+$ & $\mathrm{S}+, \mathrm{S}$ & $\mathrm{S}+$ & $\mathrm{S}+$ \\
\hline DCM & $\mathrm{PS}+, \mathrm{S}$ & $\mathrm{S}+, \mathrm{S}$ & $\mathrm{PS}+, \mathrm{S}, \mathrm{P}$ & $\mathrm{S}+$ \\
\hline $\mathrm{CCl}_{4}$ & $\mathrm{PS}+, \mathrm{PS}$ & $\mathrm{PS}+, \mathrm{PS}$ & $\mathrm{PS}+, \mathrm{PS}$ & $\mathrm{PS}+, \mathrm{PS}$ \\
\hline Benzene & PS+, PS, G & PS, S & $\mathrm{PS}+, \mathrm{PS}$ & $\mathrm{PS}+, \mathrm{PS}$ \\
\hline Chlorobenzene & $\mathrm{PS}+, \mathrm{S}, \mathbf{G}$ & $\mathrm{PS}+, \mathrm{S}$ & $\mathrm{PS}+, \mathrm{S}$ & $\mathrm{PS}+, \mathrm{S}$ \\
\hline tert-Butylbezene & $\mathrm{PS}+, \mathrm{S}$ & $\mathrm{PS}+, \mathrm{PS}$ & $\mathrm{PS}+, \mathrm{S}$ & $\mathrm{PS}+, \mathrm{S}, \mathrm{P}$ \\
\hline Toluene & $\mathrm{PS}+, \mathrm{PS}, \mathbf{G}$ & $\mathrm{PS}+, \mathrm{S}, \mathrm{PS}$ & $\mathrm{PS}+, \mathrm{S}$ & $\mathrm{PS}+, \mathrm{S}$ \\
\hline$p$-Xylene & $\mathrm{PS}+, \mathrm{S}, \mathbf{G}$ & $\mathrm{PS}+, \mathrm{S}, \mathrm{PS}$ & $\mathrm{PS}+, \mathrm{S}$ & $\mathrm{PS}+, \mathrm{PS}$ \\
\hline$m$-Xylene & $\mathrm{PS}+, \mathrm{S}, \mathrm{PG}$ & $\mathrm{PS}+, \mathrm{S}, \mathrm{PS}$ & $\mathrm{PS}+, \mathrm{S}$ & $\mathrm{PS}+, \mathrm{PS}$ \\
\hline$o$-Xylene & $\mathrm{PS}+, \mathrm{S}, \mathbf{G}$ & $\mathrm{PS}+, \mathrm{S}, \mathrm{PS}$ & $\mathrm{PS}+, \mathrm{S}$ & $\mathrm{PS}+, \mathrm{S}$ \\
\hline Cumene & $\mathrm{PS}+, \mathrm{S}$ & PS & $\mathrm{PS}+, \mathrm{S}$ & $\mathrm{PS}+, \mathrm{PS}$ \\
\hline Mesitylene & $\mathrm{PS}+, \mathrm{S}, \mathrm{PG}$ & $\mathrm{PS}+, \mathrm{S}, \mathrm{PS}$ & $\mathrm{PS}+, \mathrm{S}$ & $\mathrm{PS}+, \mathrm{S}$ \\
\hline Anisole & $\mathrm{PS}+, \mathbf{S}, \mathbf{G}^{\mathrm{a}}$ & $\mathrm{PS}+, \mathrm{S}, \mathrm{PS}$ & $\mathrm{PS}+, \mathrm{S}$ & $\mathrm{PS}+, \mathrm{S}$ \\
\hline Cyclohexene & $\mathrm{S}+$ & $\mathrm{PS}+, \mathrm{S}$ & $\mathrm{S}+$ & $\mathrm{PS}+, \mathrm{S}, \mathrm{P}$ \\
\hline Ethylacetate & $\mathrm{PS}+, \mathrm{PS}, \mathrm{PG}$ & $\mathrm{PS}+, \mathrm{S}$ & $\mathrm{PS}+, \mathrm{S}, \mathrm{P}$ & $\mathrm{PS}+, \mathrm{S}$ \\
\hline Hexane & $\mathrm{PS}+, \mathrm{PS}$ & $\mathrm{PS}+, \mathrm{PS}, \mathrm{P}$ & $\mathrm{PS}+, \mathrm{PS}$ & $\mathrm{PS}+, \mathrm{PS}, \mathrm{P}$ \\
\hline Acetone & $\mathrm{PS}+, \mathrm{PS}, \mathbf{G}$ & $\mathrm{PS}+, \mathrm{S}$ & $\mathrm{PS}+, \mathrm{S}$ & $\mathrm{PS}+, \mathrm{S}$ \\
\hline $\mathrm{ACN}$ & $\mathrm{PS}+, \mathrm{PS}, \mathbf{G}$ & - & $\mathrm{PS}+, \mathrm{S}$ & $\mathrm{S}+$ \\
\hline DMF & $\mathrm{PS}+, \mathrm{S}$ & $\mathrm{S}+, \mathrm{S}$ & $\mathrm{S}+$ & $\mathrm{S}+$ \\
\hline Acetic acid & $\mathrm{S}+$ & $\mathrm{S}+, \mathrm{S}$ & $\mathrm{S}+$ & $\mathrm{S}+$ \\
\hline THF & $\mathrm{S}+$ & $\mathrm{S}+, \mathrm{S}$ & $\mathrm{S}+$ & PS+, S \\
\hline $\mathrm{MeOH}$ & $\mathrm{S}+$ & $\mathrm{S}+, \mathrm{S}$ & $\mathrm{S}+$ & $\mathrm{PS}+, \mathrm{S}, \mathrm{P}$ \\
\hline $\mathrm{EtOH}$ & $\mathrm{S}+$ & $\mathrm{S}+, \mathrm{S}$ & $\mathrm{PS}+, \mathrm{S}$ & $\mathrm{PS}+, \mathrm{PS}$ \\
\hline 2-Propanol & $\mathrm{S}+$ & $\mathrm{S}+, \mathrm{S}$ & $\mathrm{S}+$ & $\mathrm{PS}+, \mathrm{PS}$ \\
\hline 1-Butanol & $\mathrm{S}+$ & $\mathrm{S}+, \mathrm{S}$ & $\mathrm{S}+$ & $\mathrm{PS}+, \mathrm{S}, \mathrm{P}$ \\
\hline 1-Octanol & $\mathrm{S}+$ & $\mathrm{PS}+, \mathrm{S}$ & $\mathrm{S}+$ & $\mathrm{PS}+, \mathrm{S}, \mathrm{P}$ \\
\hline Cyclohexanol & $\mathrm{PS}+, \mathrm{S}$ & $\mathrm{PS}+, \mathrm{S}$ & $\mathrm{PS}+, \mathrm{S}$ & $\mathrm{PS}+, \mathrm{S}$ \\
\hline $2 \mathrm{M} \mathrm{HCl}$ & $\mathrm{PS}+, \mathrm{PS}, \mathrm{P}$ & $\mathrm{PS}+, \mathrm{PS}$ & $\mathrm{PS}+, \mathrm{PS}$ & $\mathrm{PS}+, \mathrm{PS}, \mathrm{P}$ \\
\hline Deionized $\mathrm{H}_{2} \mathrm{O}$ & $\mathrm{PS}+, \mathrm{PS}, \mathrm{P}$ & $\mathrm{PS}+, \mathrm{PS}, \mathrm{P}$ & $\mathrm{PS}+, \mathrm{PS}, \mathrm{P}$ & $\mathrm{S}+$ \\
\hline Pyridine & $\mathrm{S}+$ & $\mathrm{S}+, \mathrm{S}$ & $\mathrm{S}+$ & $\mathrm{PS}+, \mathrm{PS}$ \\
\hline
\end{tabular}


$\mathrm{S}+=$ soluble without heating, $\mathrm{S}=$ soluble with heating, $\mathrm{PS}=$ partially soluble with heating, $\mathrm{I}=$ insoluble, $\mathrm{G}=$ gel with appr. 0-5 \% free solvent, $\mathrm{G}-=$ gel with appr. 5-20\% free solvent, $\mathrm{G}^{\mathrm{a}}=$ gel formed after one day, $\mathrm{PG}=$ gel with appr. $50 \%$ free solvent, $\mathrm{P}=$ precipitates on cooling.

Table 2: Gelation test results for compounds 1-4 at $1 \%(\mathrm{w} / \mathrm{v})$ concentration in aqueous solutions.

\begin{tabular}{|c|c|c|c|c|}
\hline & 1 & 2 & 3 & 4 \\
\hline $\begin{array}{l}\text { 50:50 } \\
\mathrm{H}_{2} \mathrm{O}: \mathrm{MeOH}\end{array}$ & $\mathrm{PS}+, \mathrm{PS}, \mathrm{P}$ & $\mathrm{PS}+, \mathrm{S}, \mathrm{P}$ & $\mathrm{PS}+, \mathrm{PS}$ & PS \\
\hline $\mathrm{H}_{2} \mathrm{O}: \mathrm{EtOH}$ & PS, P & $S$ & $S$ & \\
\hline $\mathrm{H}_{2} \mathrm{O}$ :acetone & PS, P & $\mathrm{S}$ & $S$ & S \\
\hline $\mathrm{H}_{2} \mathrm{O}: \mathrm{ACN}$ & PS, P & $\mathrm{S}, \mathrm{P}$ & $\mathrm{S}$ & $\mathrm{S}, \mathrm{P}$ \\
\hline $\mathrm{H}_{2} \mathrm{O}$ :2-propanol & PS, $\mathrm{P}$, gel-like & $S$ & $\mathrm{~S}$ & $\mathrm{~S}+$ \\
\hline $\begin{array}{l}\text { 60:40 } \\
\mathrm{H}_{2} \mathrm{O}: \mathrm{MeOH}\end{array}$ & $\mathrm{PS}+, \mathrm{PS}, \mathrm{P}$ & $\mathrm{PS}+, \mathrm{PS}, \mathrm{P}$ & $\mathrm{PS}+, \mathrm{S}, \mathrm{PS}$ & $\mathrm{PS}+, \mathrm{PS}$ \\
\hline $\mathrm{H}_{2} \mathrm{O}: \mathrm{EtOH}$ & PS, P & $\mathrm{S}, \mathrm{P}$ & $\mathrm{S}$ & PS, P \\
\hline $\begin{array}{l}\text { 70:30 } \\
\mathrm{H}_{2} \mathrm{O}: \mathrm{MeOH} \\
\mathrm{H}_{2} \mathrm{O}: \mathrm{EtOH}\end{array}$ & $\begin{array}{l}\text { PS+, PS, G } \\
\text { PS, P }\end{array}$ & $\begin{array}{l}\mathrm{PS}+ \\
\text { suspension } \\
\mathrm{PS}, \mathrm{P}\end{array}$ & $\begin{array}{l}\text { PS+, PS, S } \\
\text { S+, P }\end{array}$ & $\begin{array}{l}\mathrm{PS}+, \mathrm{PS} \\
\mathrm{PS}, \mathrm{P}\end{array}$ \\
\hline $\begin{array}{l}\text { 80:20 } \\
\mathrm{H}_{2} \mathrm{O}: \mathrm{EtOH}\end{array}$ & PS, P & $\mathrm{S}+, \mathrm{P}$ & PS, P & PS, P \\
\hline $\begin{array}{l}\text { 10:90 } \\
\mathrm{H}_{2} \mathrm{O}: \mathrm{EtOH}\end{array}$ & & $\mathrm{S}+$ & $\mathrm{S}+$ & $\mathrm{S}+$ \\
\hline $\mathrm{H}_{2} \mathrm{O}$ :acetone & S, G- & S+ & $\mathrm{S}$ & $\mathrm{S}$ \\
\hline $\mathrm{H}_{2} \mathrm{O}: \mathrm{ACN}$ & $\mathrm{S}+, \mathrm{P}$, gel-like & $\mathrm{S}$ & $\mathrm{S}$ & $\mathrm{S}$ \\
\hline $\mathrm{H}_{2} \mathrm{O}: 2$-propanol & $\mathrm{S}+$ & $\mathrm{S}+$ & $\mathrm{S}$ & S+ \\
\hline $\begin{array}{l}\mathbf{2 0 : 8 0} \\
\mathrm{H}_{2} \mathrm{O}: \mathrm{EtOH}\end{array}$ & $\mathrm{S}$ & $\mathrm{S}+$ & $\mathrm{S}+$ & $\mathrm{S}+$ \\
\hline $\begin{array}{l}30: 70 \\
\mathrm{H}_{2} \mathrm{O}: \mathrm{EtOH}\end{array}$ & $\mathrm{S}+$ & $S$ & $\mathrm{~S}$ & $\mathrm{~S}+$ \\
\hline $\mathrm{H}_{2} \mathrm{O}$ :acetone & PS, P & $\mathrm{S}$ & $\mathrm{S}$ & $\mathrm{S}$ \\
\hline $\mathrm{H}_{2} \mathrm{O}: \mathrm{ACN}$ & PS, P & $\mathrm{S}$ & $\mathrm{S}$ & $\mathrm{S}+, \mathrm{P}$ \\
\hline $\mathrm{H}_{2} \mathrm{O}: 2$-propanol & $\mathrm{S}$ & $\mathrm{S}$ & $\mathrm{S}$ & S+ \\
\hline
\end{tabular}


$\mathrm{S}+=$ soluble without heating, $\mathrm{S}=$ soluble with heating, $\mathrm{PS}=$ partially soluble with heating, $\mathrm{I}=$ insoluble, $\mathrm{G}=$ gel with appr. 0-5 \% free solvent, $\mathrm{G}-=$ gel with appr. 5-20\% free solvent, $\mathrm{G}^{\mathrm{a}}=$ gel formed after one day, $\mathrm{P}=$ precipitates on cooling.

A total of 19 gel systems were obtained, most of which in aromatic solvents. Five of the obtained gel systems were partial gels. Aromatic solvents included benzene, chlorobenzene, tertbutylbenzene, toluene, $p$ - and $o$-xylene, and anisole. Compound $\mathbf{1}$ formed gels in acetone and acetonitrile in addition to aromatic solvents. Partial gels of compound $\mathbf{1}$ formed in $m$-xylene, mesitylene, and ethylacetate. Compound 4 formed $2 \%$ (w/v) gel in ethanol and a $2 \%$ (w/v) weak gel in 2-propanol. Lithocholic acid derivative 1 formed the majority of the gel systems, a total of 16 gel systems, which is common for bile acid derivatives. For example, most of the gel systems from the bile acid cysteamine and alkylamide derivatives reported previously by our research group tended to be formed by lithocholic acid derivatives ${ }^{37,38}$. Some of the gel systems in previous studies were obtained with dehydrocholic acid derivatives, as well ${ }^{35}$.

In the present study we found that lithocholic acid derivative $\mathbf{1}$ had interesting properties in water solutions. The solution systems for $1 \%(\mathrm{w} / \mathrm{v})$ hydrogelation tests were selected based on the gel systems obtained in organogelation tests. Furthermore, the solution systems for $2 \%(\mathrm{w} / \mathrm{v})$ hydrogelation tests were chosen based on results from previously conducted $1 \%(\mathrm{w} / \mathrm{v})$ hydrogelation tests. Compound $\mathbf{1}$ generated five hydrogel systems, of which three were strong gels. The $1 \%\left(\mathrm{w} / \mathrm{v}\right.$ ) weak gel by compound 1 formed in 10:90 $\mathrm{H}_{2} \mathrm{O}$ :acetone. Two of the three strong gels by compound 1 formed as $2 \%(\mathrm{w} / \mathrm{v})$ in 50:50 $\mathrm{H}_{2} \mathrm{O}$ :2-propanol and 10:90 $\mathrm{H}_{2} \mathrm{O}$ acetonitrile. One strong gel formed as $1 \%(\mathrm{w} / \mathrm{v})$ in $70: 30 \mathrm{H}_{2} \mathrm{O}: \mathrm{MeOH}$. Compound 1 also formed a partial gel as $2 \%$ (w/v) in 10:90 $\mathrm{H}_{2} \mathrm{O}$ :acetone. In addition to actual gel systems, compound $\mathbf{1}$ formed gel-like systems as $1 \%(\mathrm{w} / \mathrm{v})$ in 50:50 $\mathrm{H}_{2} \mathrm{O}$ :2-propanol and 10:90 $\mathrm{H}_{2} \mathrm{O}$ :acetonitrile. Compound 2 was found to create partial gel as $2 \%(\mathrm{w} / \mathrm{v})$ in 70:30 $\mathrm{H}_{2} \mathrm{O}: \mathrm{MeOH}$. Interestingly, the three proper hydrogels disintegrated instantly when disturbed with a spatula making them thixotropic by nature. The same phenomenon was observed for compound $11 \%(\mathrm{w} / \mathrm{v})$ gel in acetonitrile when preparing the SEM samples.

\subsection{IR}

The IR spectra of the solid compounds 1-4 were very similar with each other showing just a little variation in the amide bond's carbonyl stretching mode (Table 3). The solid compound $\mathbf{1}$ and the 
$2 \%$ hydrogels (50:50 $\mathrm{H}_{2} \mathrm{O}$ :2-propanol, 10:90 $\mathrm{H}_{2} \mathrm{O}$ acetone and $\mathrm{H}_{2} \mathrm{O}$ :acetonitrile) of compound 1 were rather uniform when compared to each other. In the spectrum of $2 \%(\mathrm{w} / \mathrm{v})$ hydrogel of compound 1 in 10:90 $\mathrm{H}_{2} \mathrm{O}$ :acetone, however, a broad band at 3300-3500 $\mathrm{cm}^{-1}$ was observed (Figure 2), probably due to hydrogen bonding of the gelator molecules. Since, based on X-ray crystallography, hydrogen bonding is important in stabilizing the solid state structures, and since the difference to the spectrum of solid compound $\mathbf{1}$ is so small, hydrogen bonding in not necessarily the only driving force in the gel network formation.

Table 3: Selected IR bands for compounds 1-4 and hydrogels of compound $\mathbf{1}$.

\begin{tabular}{|l|l|l|l|l|}
\hline Sample & Amide I $\left(\mathrm{cm}^{-1}\right)$ & Amide II $\left(\mathrm{cm}^{-1}\right)$ & Amide B $\left(\mathrm{cm}^{-1}\right)$ & $v$ NH/OH $\left(\mathrm{cm}^{-1}\right)$ \\
\hline $\mathbf{1}$ & 1655 & 1546 & 2932 & 3325,3432 \\
\hline $\mathbf{2}$ & 1624 & 1530 & 2926 & 3369 \\
\hline $\mathbf{3}$ & 1612 & 1557 & 2927 & $3281,3419,3511$ \\
\hline $\mathbf{4}$ & 1701 & 1543 & 2970 & 3287,3391 \\
\hline $\begin{array}{l}2 \% \mathbf{1} \text { in 50:50 } \mathrm{H}_{2} \mathrm{O}: 2- \\
\text { propanol }\end{array}$ & 1655 & 1545 & 2932 & 3322,3431 \\
\hline $\begin{array}{l}2 \% \mathbf{1} \text { in 10:90 } \mathrm{H}_{2} \text { O:acet- } \\
\text { one }\end{array}$ & 1655 & 1545 & 2932 & 3326,3435 \\
\hline $\begin{array}{l}2 \% \mathbf{1} \text { in 10:90 } \mathrm{H}_{2} \text { O:acet- } \\
\text { onitrile }\end{array}$ & 1655 & 1545 & 2932 & 3324,3434 \\
\hline
\end{tabular}




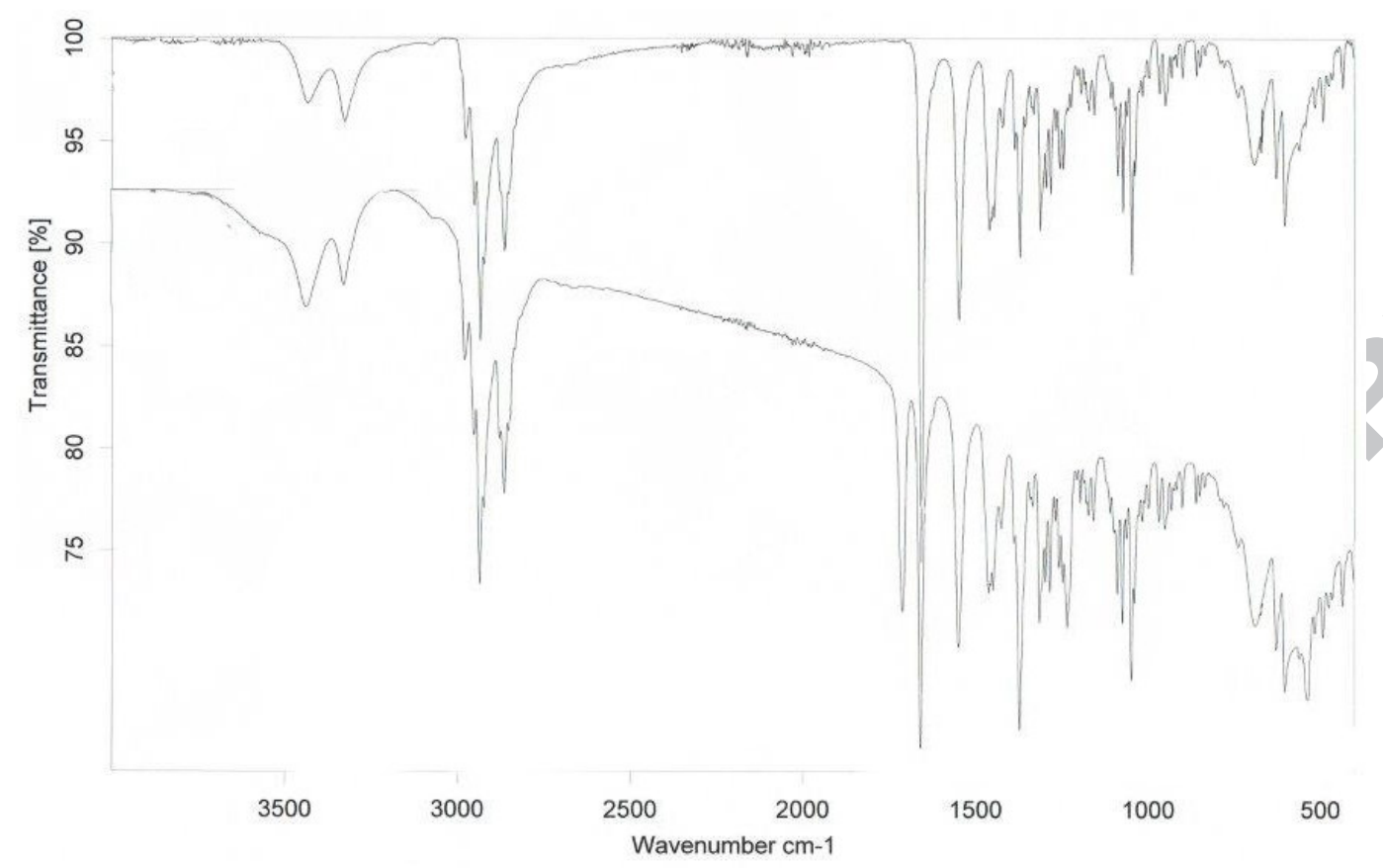

Figure 2: IR spectra of compound 1 (above) and $2 \%(w / v)$ gel of compound 1 in 10:90 H2O:acetone (below).

\subsection{Microscopy}

The hydrogels formed by compound 1 were studied with scanning electron microscope (SEM). When comparing the SEM images of gels formed by compound $\mathbf{1}$ in aqueous solutions, it was found that the self-assembly patterns diverge from each other depending on the method of sample preparation. In the case of samples prepared from hot solutions, gel fibers resembled stalks of grass. However, gelator molecules appeared to form spherical assemblies consisting of fiber bundles resembling old fashioned dusters in samples prepared from gels directly. The assemblies of these bundles were a spitting image of dandelions fluffy seeds. This was most clearly seen in images of the $2 \%(\mathrm{w} / \mathrm{v})$ gel of compound 1 in 50:50 $\mathrm{H}_{2} \mathrm{O}: 2$-propanol (Figure 3).

In all the gels studied the fiber sizes were similar. Straight fibers in samples prepared from hot solutions varied in width between 1-15 $\mu \mathrm{m}$ and in length between 20-240 $\mu \mathrm{m}$. In samples prepared by scooping a portion of the gel on the sample stub single fibers were similar in width compared to stalk like fibers. However, the single fibers were longer, the length varied between $60-410 \mu \mathrm{m}$. The diameter of the spherical assemblies varied between 390-740 $\mu \mathrm{m}$. 


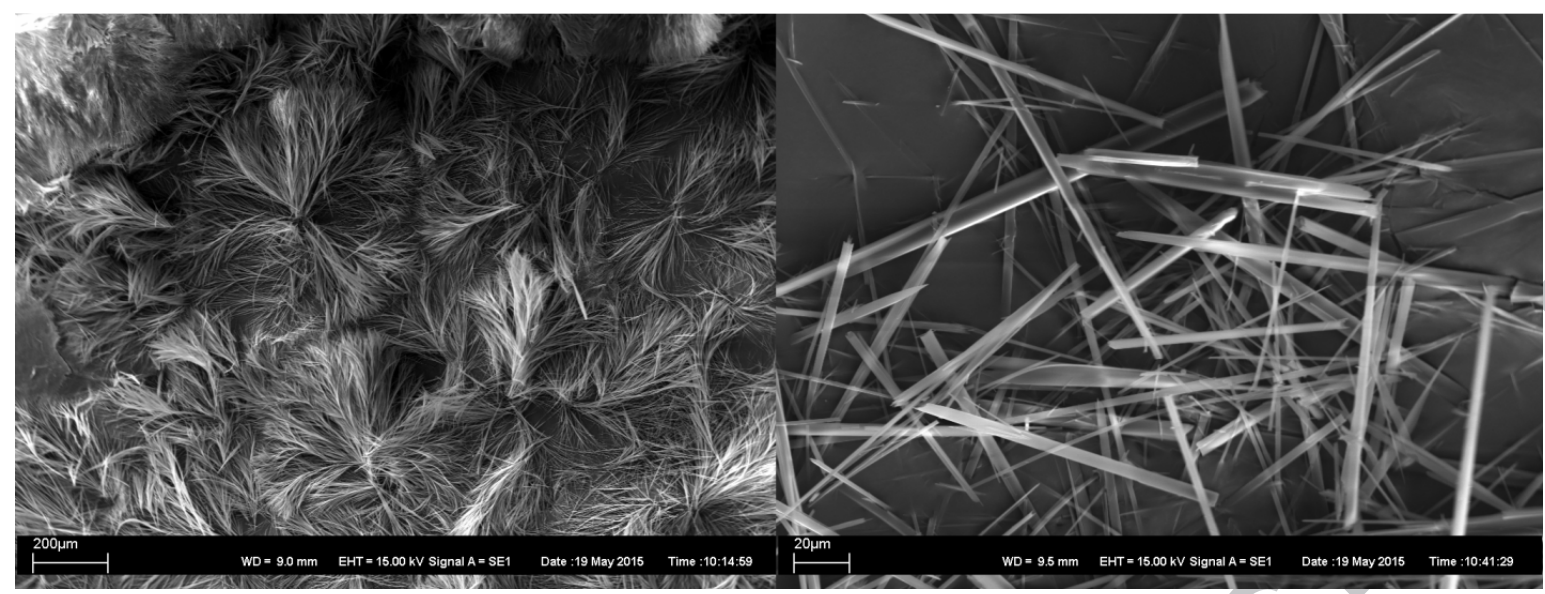

Figure 3: $2 \%(\mathrm{w} / \mathrm{v})$ gel of compound 1 in 50:50 $\mathrm{H}_{2} \mathrm{O}$ :2-propanol. Sample prepared from gel (left) and sample prepared from hot solution (right).

\subsection{Results of the neutral red assay}

The standard mouse cell line Balb/c 3T3, commonly used in accredited tests, was used for the toxicity study. The neutral red (NR) assay was performed for compounds 1-4 (see Equation E1 and Figures S1-S4). It is based on the fact that live (non-damaged) cells intake and store NR into their lysosomes, and the concentration of the incorporated dye can then be determined spectrophotometrically. The toxicity data are expressed as $\mathrm{IC}_{50} \pm$ S.D. $(\mu \mathrm{g} / \mathrm{ml})$ values. Substances efficiency in inhibiting specific biochemical or biological function is described as the half maximal inhibitory concentration $\left(\mathrm{IC}_{50}\right)$. As can be seen from Table 4 , the highest cell viability in the series of compounds was shown by compound 3, which did not form any gels. Compound 1, which formed hydrogels, showed third lowest toxicity in the series. In a previous study performed by us for bile acid-cysteamine conjugates ${ }^{35}$ it was observed that the hydroxyl group in position $7 \alpha$ and/or $12 \alpha$ might cause the compound to show toxicity, whereas the non-toxic compounds only had a $3 \alpha-$ hydroxyl, $3 \alpha$ - and 7 $\beta$-hydroxyls, or no hydroxyl groups at all. The current results don't agree with those hypotheses, even though compound $\mathbf{4}$ bearing no hydroxyls shows the second lowest toxicity in the series. 
Table 4: Toxicity of tested compounds evaluated using NR assay.

\begin{tabular}{|l|l|l|}
\hline Compounds & Concentration range $(\boldsymbol{\mu g} / \mathbf{m l})$ & $\mathbf{I C}_{\mathbf{5 0}} \pm$ S.D. $(\boldsymbol{\mu g} / \mathbf{m l})$ \\
\hline 1 & $0.2-25$ & $22.70 \pm 2.16$ \\
\hline 2 & $0.2-25$ & $12.31 \pm 2.08$ \\
\hline 3 & $0.8-100$ & $73.50 \pm 4.58$ \\
\hline 4 & $0.8-100$ & $* 65.17 \pm 3.30$ \\
\hline
\end{tabular}

* Cell viability evaluated at the highest concentration express as \% of control

\subsection{X-ray crystallography}

Despite many bile acid crystal structures have characteristic bilayer hydrogen bonding, the position and number of hydroxyl groups on the amphiphilic face play an important role to form a variety of hydrogen bonded supramolecular networks. These robust facial amphiphiles with different number of hydroxyl groups are carefully engineered for different applications e.g. micellar and interactions with biological membranes. ${ }^{47-49}$ Another appealing solid-state property, which leads to remarkable lattice stabilization patterns, is their side chain modification. Modifications of side chains in bile acids have been extensively reviewed ${ }^{50-54}$ and unarguably the conformations adopted by side-chains has represented wide range of applications in the field of crystal engineering, co-crystals, improved biological activity, and pharmaceutical applications. In the current study, inspired by the gelation properties, single crystals of $N$-ethylamide derivatives of lithocholic acid (1), deoxycholic acid (2) and cholic acid (3) were grown from acetonitrile by solvent evaporation to study the effect of inclusion of amide functionality to the hydrogen bonded bilayers.

Compound 1 crystallized in the monoclinic space group $P 2_{1}$ with one molecule in the asymmetric unit. As can be seen from Figure $4 \mathrm{a}$ the peripheral hydroxyl group at $3 \alpha$-position and the $N$ alkylamide side chain with $t t t$ conformation $^{55}$ are orientated in the same direction. As a result, the hydroxyl group at $3 \alpha$-position as well as the carbonyl and N-H groups in the side-chain drive $\mathbf{1}$ to give infinite one-dimensional bilayers stabilized by $\mathrm{O}-\mathrm{H} \bullet \bullet \mathrm{O}[d(\mathrm{O} \bullet \bullet \mathrm{O}), 2.857(3) \AA]$ and $\mathrm{N}-\mathrm{H} \bullet \bullet \mathrm{O}$ 
$[d(\mathrm{~N} \bullet \bullet \mathrm{O}), 3.083(3) \AA]$ interactions (Figure 4b). Compound 2, however, crystallized in the triclinic space group $P-1$ containing three crystallographically independent molecules of 2 (see Table $\mathrm{S} 1$ ) and four acetonitrile molecules in the asymmetric unit. The dihedral angles C13-C17-C20-C22, $\mathrm{C} 17-\mathrm{C} 20-\mathrm{C} 22-\mathrm{C} 23, \mathrm{C} 20-\mathrm{C} 22-\mathrm{C} 23-\mathrm{C} 24$, and $\mathrm{C} 22-\mathrm{C} 23-\mathrm{C} 24-\mathrm{N} 24$ (Table 5) for all the three molecules in the asymmetric unit are close to ttgt conformations. The hydroxyl groups at $12 \alpha-$ positions, the carbonyl oxygens, and the $\mathrm{N}-\mathrm{H}$ groups form intermolecular $\mathrm{O}-\mathrm{H} \bullet \bullet \mathrm{O}$ and $\mathrm{N}-\mathrm{H} \bullet \bullet \mathrm{O}$ hydrogen bonds while the peripheral hydroxyl groups at $3 \alpha$-positions hydrogen bonds to acetonitrile molecules (Figure 4c). Although the molecule has features to crystallize in high symmetry space groups with screw axes, the hydroxyl groups at $12 \alpha$-position and the fourth acetonitrile molecule presumably destroy the symmetry to bring molecules closer to form $\mathrm{O}-\mathrm{H} \bullet \bullet \bullet \mathrm{O}$ and $\mathrm{N}-\mathrm{H} \bullet \bullet \mathrm{O}$ interactions giving 2 wriggly motifs. The intermolecular hydrogen bond between the three bile acid molecules contributes to the induction of a 1-D columnar type assembly, possessing analogous features of helices, as shown in Figure 4d. A perspective view of the crystal packing in 2 suggests that the self-organization in bile acids is dependent on positions of the hydroxyl groups and on the side chain conformations.

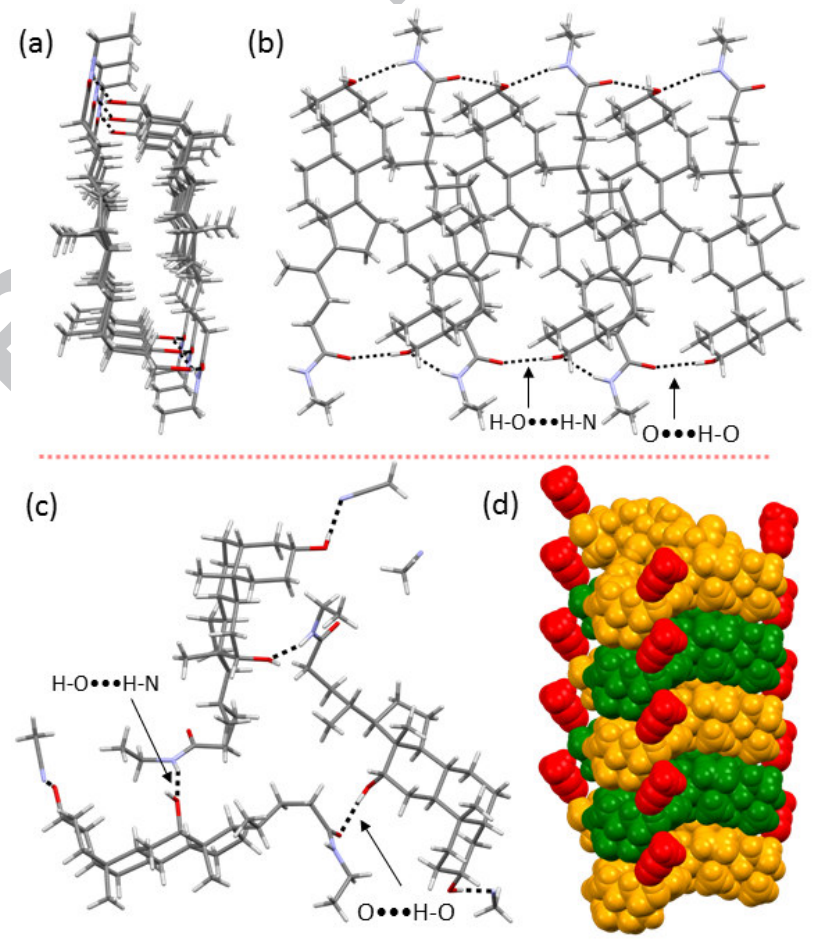

Figure 4. (a) 1-D Polymeric structure of 1, and (b) side-view to show $3 \alpha$-hydroxyl group and $N$ ethylamide chain orientation in capped stick model. (c) Top-view of 1-D hydrogen bonded trimeric 
structure of 2 in capped stick model. (d) Side-view to stacking arrangement of trimers in $\mathbf{2}$ in CPK model. Representation: Orange and green - compound 2, and red - acetonitrile. Black broken lines represent hydrogen bonding.

Compound 3 crystallized in the monoclinic space group $C 2$, the asymmetric unit containing two crystallographically independent molecules of $\mathbf{3}$ and an acetonitrile molecule. The structural difference in the side chains with $t g t g$ and $t t t$ conformations, and the intermolecular $\mathrm{N}-\mathrm{H} \bullet \bullet \cdot \mathrm{O}$ connectivity resulted in twice the unit cell $a$-axis length of $\mathbf{1}$, as shown in Figure 5a. The side chain with the tgtg conformation carrying an $\mathrm{N}-\mathrm{H}$ group, and the hydroxyl groups of amphiphilic face of compound 3 give a bilayer structure by $\mathrm{O}-\mathrm{H} \bullet \bullet \mathrm{O}$ and $\mathrm{O}-\mathrm{H} \bullet \bullet \mathrm{O}$ interactions. On the other hand, the side chain with $t t t$ conformation carrying the N-H group hydrogen bonds directly to an acetonitrile molecule as shown in Figure 5b.
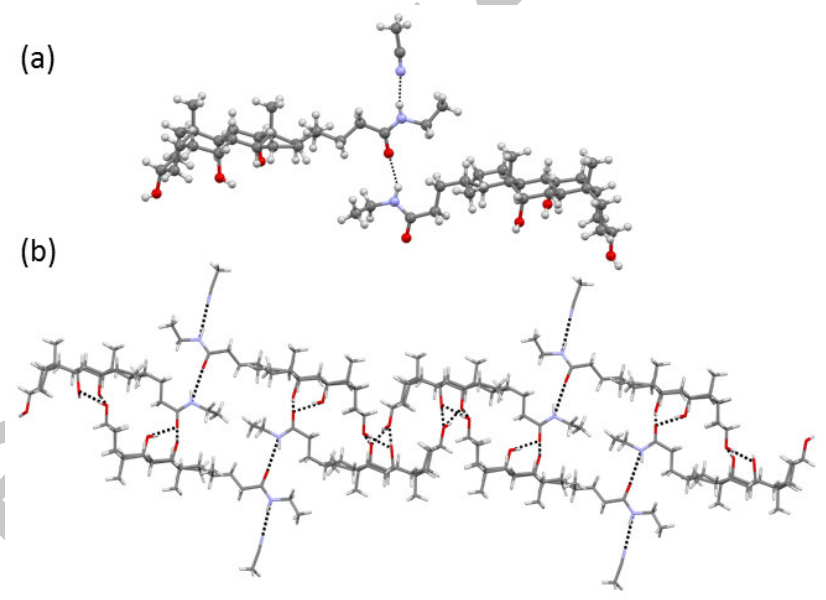

Figure 5. (a) Asymmetric unit of $\mathbf{3}$ in ball and stick model, and (b) section of crystal packing to show bilayer formation (capped stick model). Hydrogen and solvent molecules are omitted for clarity. Black broken lines represent hydrogen bonding. 
Table 5: Dihedral angles of the side-chains $\left(^{\circ}\right)$ of 1, 2, and 3.

\begin{tabular}{|l|c|c|c|}
\hline & $\mathbf{1}$ & $\mathbf{2}$ & $\mathbf{3}$ \\
\hline C13-C17-C20-C22 & $174.3(2)$ & $-174.0(2)$ & $175.3(3)[169.5(3)]$ \\
\hline C17-C20-C22-C23 & $-173.5(2)$ & $-174.0(2)$ & $59.4(4)[-156.9(3)]$ \\
\hline C20-C22-C23-C24 & $172.6(2)$ & $72.3(3)$ & $178.9(3)[-163.8(4)]$ \\
\hline C22-C23-C24-N24 & $136.3(2)$ & $-125.9(3)$ & $-3.6(5)[-155.0(4)]$ \\
\hline
\end{tabular}

The bilayered structures formed by $\mathrm{O}-\mathrm{H} \bullet \bullet \mathrm{O}$ interactions are robust, and the structural rigidity gives the lipophilic faces a characteristic corrugated property. The repulsion between methyl groups in the crystal packing makes the lipophilic face offset stabilized by hydrogen bonding and van der Waals interactions. As a result, based on the interdigitation of C18 and $\mathrm{C} 19$ methyl groups in lipophilic face and two possible conformations of the side chain, the host frameworks in these crystal structures were classified into four types; $\alpha$-gauche, $\beta$-trans, $\beta$-gauche, and $\alpha$-trans. ${ }^{56}$ The side chain dihedral angle (C17-C20-C22-C23) is generally used to distinguish the four types. The side chain with tgtg conformation has dihedral angle (C17-C20-C22-C23) of 59.4(4) ${ }^{\circ}$, which corresponds to $\alpha$-gauche type, whereas the interdigitation of methyl group suggests the hostframework being of $\beta$-gauche type. On the other hand, the side chain with $t t t$ conformation has a dihedral angle (C17-C20-C22-C23) of $-156.9(3)^{\circ}$, in which the stacking associates uniquely to $\alpha$ trans type, as shown in Fig 6. To the best of our knowledge, two host framework arrangements identified within a crystal packing has not been previously reported.

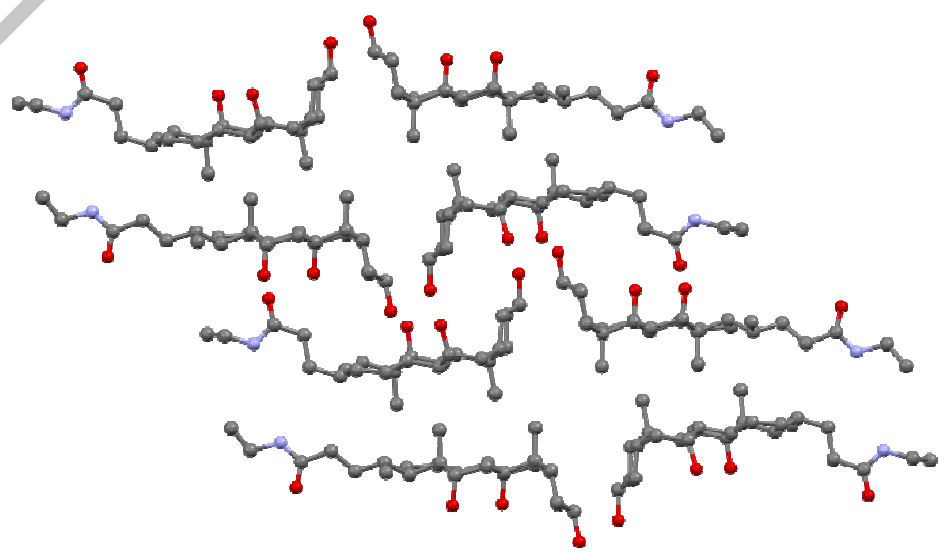


Figure 6: Section of crystal packing viewed along $b$-axis to show $\alpha$-gauche and $\alpha$-trans type host arrangements in $\mathbf{3}$, in ball and stick model. Hydrogen and solvent molecules are omitted for clarity.

During crystallizations, most bile acids prefer anhydrous form due to bilayered $\mathrm{O}-\mathrm{H} \bullet \bullet \mathrm{O}$ interactions, and thus can adopt significant conformational changes for side chains in co-crystals. Bile acids without hydroxyl groups are often and sometimes difficult to crystallize. For example in the current study, attempts to obtain good quality crystals of compound $\mathbf{4}$ were unsuccessful. Thin needle shape crystals were obtained after boiling $\mathbf{4}$ overnight in 1:1 water:methanol solvent ratio (data completeness < IUCr limit). However, the crystal structure shows that the lattice stabilization occurs uniquely at $\mathrm{N}-\mathrm{H}$ functional group with methanol and water molecules.

Crystal data and X-ray experimental details for compounds 1, 2, and 3 are presented in Table S2.

\section{Conclusions}

As a continuation of the series of bile acid alkyl or functionalized alkyl amide/ester derivatives capable of acting as gelators, in this work four new bile acid ethyl amide derivatives were synthesized and characterized in detail. Gelation experiments for the synthesized molecules resulted in a total of 19 gel systems, most of which in aromatic solvents. Lithocholic acid derivative $\mathbf{1}$ formed the majority of the gel systems, which is common for bile acid derivatives. Furthermore, compound 1 generated five hydrogel systems, which showed thixotropic nature. For the best of our knowledge, this is the first time when supramolecular hydrogels involving bile acid alkyl amides is reported. The properties of the hydrogels were investigated using SEM and IR spectroscopy, and the toxicity of the compounds determined. Solid state packing of compounds 1-3 was defined by using single crystal X-ray crystallography. The packing patterns may provide an idea about the gel state assembly of the molecules, eventually shedding light to the phenomena underlying gel formation.

Bile acid-based hydrogels have potential use in biological applications both because they form in biocompatible solvents and because they are formed by nontoxic endogenous gelators. The biocompatibility of a hydrogel provides perhaps new potential applications regarding biomedicine, such as drug delivery, artificial tissue engineering, etc. 


\section{Acknowledgements}

Ellen and Artturi Nyysönen Foundation (R.K.) is acknowledged for financial support. The authors are grateful to Lab. Eng. E. Haapaniemi for NMR spectroscopy measurements and Lab. Tech. H. Salo for SEM studies.

\section{References}

$1 \quad$ A. F. Hofmann and L. R. Hagey, Cell. Mol. Life Sci., 2008, 65, 2461-83.

2 M. J. Monte, J. J. G. Marin, A. Antelo and J. Vazquez-Tato, World J. Gastroenterol., 2009, 15, 804-16.

3 S. Mukhopadhyay and U. Maitra, Curr. Sci., 2004.

4 A. F. Hofmann, News Physiol Sci, 1999, 14, 24-29.

5 E. Virtanen and E. Kolehmainen, European J. Org. Chem., 2004, 2004, 3385-3399.

6 Shamsuzzaman, H. Khanam, A. Mashrai, A. Sherwani, M. Owais and N. Siddiqui, Steroids, 2013, 78, 1263-1272.

7 K. H. Min, K. Park, Y. S. Kim, S. M. Bae, S. Lee, H. G. Jo, R. W. Park, I. S. Kim, S. Y. Jeong, K. Kim and I. C. Kwon, J. Control. Release, 2008, 127, 208-218.

8 D.-H. Kim and A. C. Larson, Biomaterials, 2015, 56, 154-164.

9 E. Im, S.-H. Choi, H. Suh, Y. H. Choi, Y. H. Yoo and N. D. Kim, Cancer Lett., 2005, 229, 49-57.

10 E. Im, Y. H. Choi, K.-J. Paik, H. Suh, Y. Jin, K.-W. Kim, Y. H. Yoo and N. D. Kim, Cancer Lett., 2001, 163, 83-93.

11 O. Briz, Mol. Pharmacol., 2003, 63, 742-750.

12 C. Valenta, E. Nowack and a Bernkop-Schnürch, Int. J. Pharm., 1999, 185, 103-111.

13 W. Kramer, G. Wess, A. Enhsen, E. Falk, A. Hoffmann, G. Neckermann, G. Schubert and M. Urmann, J. Control. Release, 1997, 46, 17-30.

14 L. Galantini, M. C. di Gregorio, M. Gubitosi, L. Travaglini, J. V. Tato, A. Jover, F. Meijide, V. H. Soto Tellini and N. V. Pavel, Curr. Opin. Colloid Interface Sci., 2015.

15 T. A. Al-Hilal, J. Park, F. Alam, S. W. Chung, J. W. Park, K. Kim, I. C. Kwon, I.-S. Kim, S. Y. Kim and Y. Byun, J. Control. Release, 2014, 175, 17-24. 
16 X.-Y. Jin, S.-Y. Fan, H.-W. Li, W.-G. Shi, W. Chen, H.-F. Wang and B.-H. Zhong, Chinese Chem. Lett., 2014, 25, 787-790.

17 E. Sievänen, Molecules, 2007, 12, 1859-1889.

18 S. Y. Chae, S. Son, M. Lee, M. K. Jang and J. W. Nah, J. Control. Release, 2005, 109, 330344.

19 H. H. Moon, M. K. Joo, H. Mok, M. Lee, K. C. Hwang, S. W. Kim, J. H. Jeong, D. Choi and S. H. Kim, Biomaterials, 2014, 35, 1744-1754.

20 D. Kim, D. Lee, Y. L. Jang, S. Y. Chae, D. Choi, J. H. Jeong and S. H. Kim, Eur. J. Pharm. Biopharm., 2012, 81, 14-23.

21 L. Mrózek, L. Dvořáková, Z. Mandelová, L. Rárová, A. Řezáčová, L. Plaček, R. Opatřilová, J. Dohnal, O. Paleta, V. Král, P. Drašar and J. Jampílek, Steroids, 2011, 76, 1082-1097.

22 L. Coufalová, L. Mrózek, L. Rárová, L. Plaček, R. Opatřilová, J. Dohnal, K. Král’Ová, O. Paleta, V. Král, P. Drašar and J. Jampílek, Steroids, 2013, 78, 435-453.

23 S. Banerjee, R. K. Das and U. Maitra, J. Mater. Chem., 2009, 19, 6649.

24 A. R. Hirst, B. Escuder, J. F. Miravet and D. K. Smith, Angew. Chem. Int. Ed. Engl., 2008, 47, 8002-18.

25 E. Caló and V. V. Khutoryanskiy, Eur. Polym. J., 2014, 65, 252-267.

26 P. Lee and M. A. Rogers, Langmuir, 2013, 29, 5617-21.

27 L. Yan, G. Li, Z. Ye, F. Tian and S. Zhang, Chem. Commun. (Camb)., 2014, 50, 14839-42.

28 J. W. Steed, Chem. Commun. (Camb)., 2011, 47, 1379-83.

29 S. B. Schryver, Proc. R. Soc. B Biol. Sci., 1914, 87, 366-374.

30 S. B. Schryver, Proc. R. Soc. B Biol. Sci., 1916, 89, 176-183.

31 S. B. Schryver, Proc. R. Soc. London. Ser. B, Contain. Pap. a Biol. Character, 1916, 89, 361-372.

32 M. R. Saboktakin and R. M. Tabatabaei, Int. J. Biol. Macromol., 2015, 75, 426-436.

33 V. Noponen, K. Toikkanen, E. Kalenius, R. Kuosmanen, H. Salo and E. Sievänen, Steroids, 2015, 97, 54-61.

34 V. Noponen, A. Valkonen, M. Lahtinen, H. Salo and E. Sievänen, Supramol. Chem., 2013, 25, 133-145.

35 V. Noponen, H. Belt, M. Lahtinen, A. Valkonen, H. Salo, J. Ulrichová, A. Galandáková and E. Sievänen, Steroids, 2012, 77, 193-203. 
36 V. Noponen, S. Bhat, E. Sievänen and E. Kolehmainen, Mater. Sci. Eng. C, 2008, 28, 1144 1148.

37 V. Noponen, M. Lahtinen, A. Valkonen, H. Salo, E. Kolehmainen and E. Sievänen, Soft Matter, 2010, 6, 3789.

38 M. Löfman, J. Koivukorpi, V. Noponen, H. Salo and E. Sievänen, J. Colloid Interface Sci., 2011, 360, 633-44.

39 M. Löfman, M. Lahtinen, M. Pettersson and E. Sievänen, Colloids Surfaces A Physicochem. Eng. Asp., 2015, 474, 18-28.

40 M. Löfman, M. Lahtinen, K. Rissanen and E. Sievänen, J. Colloid Interface Sci., 2015, 438, 77-86.

41 E. Virtanen, J. Tamminen, J. Linnanto, P. Mätttäri, P. Vainiotalo and E. Kolehmainen, J. Incl. Phenom. Macrocycl. Chem., 43, 319-327.

42 I. G. . Maines, M.D.; Costa, L.G.; Reed, D.J.; Sassa, S.; Sipes, Current protocols in toxicology, John Wiley \& Sons, New York, 1998.

43 CrysAlisPro 2012, Agil. Technol. Version 1.171.36.35.

44 G. M. Sheldrick, Acta Crystallogr. A., 2008, 64, 112-22.

45 O. V. Dolomanov, L. J. Bourhis, R. J. Gildea, J. A. K. Howard and H. Puschmann, J. Appl. Crystallogr., 2009, 42, 339-341.

46 A. Valkonen, M. Lahtinen, E. Virtanen, S. Kaikkonen and E. Kolehmainen, Biosens. Bioelectron., 2004, 20, 1233-41.

47 A. F. . Hofmann and B. Borgstöm, J. Clin. Invest., 1964, 43, 247-57.

48 K. M. Giacomini, S.-M. Huang, D. J. Tweedie, L. Z. Benet, K. L. R. Brouwer, X. Chu, A. Dahlin, R. Evers, V. Fischer, K. M. Hillgren, K. A. Hoffmaster, T. Ishikawa, D. Keppler, R. B. Kim, C. A. Lee, M. Niemi, J. W. Polli, Y. Sugiyama, P. W. Swaan, J. A. Ware, S. H. Wright, S. W. Yee, M. J. Zamek-Gliszczynski and L. Zhang, Nat. Rev. Drug Discov., 2010, 9, 215-36.

49 P. Lefebvre, B. Cariou, F. Lien, F. Kuipers and B. Staels, Physiol. Rev., 2009, 89, 147-91.

50 R. Pellicciari, G. Costantino, E. Camaioni, B. M. Sadeghpour, A. Entrena, T. M. Willson, S. Fiorucci, C. Clerici and A. Gioiello, J. Med. Chem., 2004, 47, 4559-69.

51 A. F. Hofmann, L. R. Hagey and M. D. Krasowski, J. Lipid Res., 2010, 51, 226-46.

52 K. Nakano, K. Aburaya, I. Hisaki, N. Tohnai and M. Miyata, Chem. Rec., 2009, 9, 124-35.

53 M. Miyata, N. Tohnai, I. Hisaki and T. Sasaki, Symmetry (Basel)., 2015, 7, 1914-1928. 
54 Tamura Rui;Miyata Mikiji (eds.), Advances in Organic Crystal Chemistry - Comprehensive Reviews, Springer, 2015.

55 S. Ikonen and E. Kolehmainen, CrystEngComm, 2010, 12, 4304.

56 K. Nakano, K. Sada, Y. Kurozumi and M. Miyata, Chemistry, 2001, 7, 209-20.

\section{Electronic Supplementary Information}

Table S1: Side chain dihedral angles for three crystallographically independent molecules in compound 2.

\begin{tabular}{lccc}
\hline & Molecule 1 & Molecule 2 & Molecule 3 \\
\hline C13-C17-C20-C22 & $-174.0(2)$ & $-172.6(2)$ & $-172.6(2)$ \\
C17-C20-C22-C23 & $-174.0(2)$ & $-171.3(3)$ & $-168.2(2)$ \\
C20-C22-C23-C24 & $72.3(3)$ & $71.3(3)$ & $69.8(3)$
\end{tabular}


$\begin{array}{llll}\mathrm{C} 22-\mathrm{C} 23-\mathrm{C} 24-\mathrm{N} 24 & -125.9(3) & -115.9(3) & -114.9(3)\end{array}$

Table S2: Crystal data and X-ray experimental details for compounds 1, 2, and 3.

\begin{tabular}{|c|c|c|c|}
\hline Compound & 1 & 2 & 3 \\
\hline CCDC No. & 1438665 & 1438666 & 1438667 \\
\hline Empirical formula & $\mathrm{C}_{26} \mathrm{H}_{45} \mathrm{NO}_{2}$ & $\mathrm{C}_{86} \mathrm{H}_{147} \mathrm{~N}_{7} \mathrm{O}_{9}$ & $\mathrm{C}_{54} \mathrm{H}_{93} \mathrm{~N}_{3} \mathrm{O}_{8}$ \\
\hline Formula weight & 403.63 & 1423.10 & 912.31 \\
\hline Temperature (K) & 123.0 & 120.0 & 123.0 \\
\hline Crystal system & Monoclinic & Triclinic & Monoclinic \\
\hline Space group & $P 2_{1}$ & $P-1$ & $C 2$ \\
\hline Unit cell dimensions: a $(\stackrel{\mathrm{A}}{)})$ & $10.7537(3)$ & $7.04914(7)$ & $48.7516(4)$ \\
\hline Unit cell dimensions: $\mathrm{b}(\stackrel{\mathrm{A}}{)})$ & $7.58178(16)$ & $18.4817(2)$ & $7.84759(7)$ \\
\hline Unit cell dimensions: c $(\AA)$ & $14.4627(4)$ & $18.8671(3)$ & $13.90755(11)$ \\
\hline Unit cell dimensions: $\alpha\left(^{\circ}\right)$ & 90 & $117.4531(13)$ & 90 \\
\hline Unit cell dimensions: $\beta\left(^{\circ}\right)$ & $97.282(3)$ & $99.2141(11)$ & $90.3673(7)$ \\
\hline Unit cell dimensions: $\gamma\left({ }^{\circ}\right)$ & 90 & $95.3368(9)$ & 90 \\
\hline Volume / $\mathrm{A}^{3}$ & $1169.66(5)$ & $2113.65(5)$ & $5320.68(7)$ \\
\hline $\mathrm{Z}$ & 2 & 1 & 4 \\
\hline Density (calculated) $\mathrm{mg} / \mathrm{m}^{3}$ & 1.146 & 1.118 & 1.139 \\
\hline Absorption Coefficient $\mathrm{mm}^{-1}$ & 0.538 & 0.557 & 0.591 \\
\hline $\mathrm{F}(000)$ & 448 & 784 & 2008 \\
\hline Crystal size $\left(\mathrm{mm}^{3}\right)$ & $0.39 \times 0.05 \times 0.40$ & $0.28 \times 0.07 \times 0.05$ & $0.25 \times 0.14 \times 0.09$ \\
\hline$\theta$ range for data collection $\left(^{\circ}\right)$ & 3.08 to 66.75 & 4.70 to 66.75 & 3.18 to 66.75 \\
\hline Reflections collected [R(int)] & $11284[0.0404]$ & $137266[0.0622]$ & $49802[0.0384]$ \\
\hline Observed reflections $[I>2 \sigma(I)]$ & 3790 & 13789 & 9012 \\
\hline Data completeness (\%) & 99.91 & 99.96 & 99.98 \\
\hline Data/ restraints/ parameters & $4078 / 1 / 274$ & $14638 / 3 / 941$ & $9284 / 2 / 612$ \\
\hline Goodness-of-fit on $\mathrm{F}^{2}$ & 1.050 & 1.042 & 1.058 \\
\hline Final $R_{1}$ indices $[I>2 \sigma(I)]$ & $\begin{array}{l}\mathrm{R}_{1}=0.0421 \\
\mathrm{wR}_{2}=0.1084\end{array}$ & $\begin{array}{l}\mathrm{R}_{1}=0.0412 \\
\mathrm{wR}_{2}=0.1032\end{array}$ & $\begin{array}{l}\mathrm{R}_{1}=0.0556 \\
\mathrm{wR}_{2}=0.1473\end{array}$ \\
\hline Final $\mathrm{R}$ indices [all data] & $\begin{array}{l}\mathrm{R}_{1}=0.0460 \\
\mathrm{wR}_{2}=0.1108\end{array}$ & $\begin{array}{l}\mathrm{R}_{1}=0.0444 \\
\mathrm{wR}_{2}=0.1063\end{array}$ & $\begin{array}{l}\mathrm{R}_{1}=0.0570 \\
\mathrm{wR}_{2}=0.1495\end{array}$ \\
\hline Largest diff. peak/hole $\left(\mathrm{e} . \AA^{-3}\right)$ & $0.218 /-0.231$ & $0.206 /-0.213$ & $0.810 /-0.505$ \\
\hline
\end{tabular}


Equation E1: Evaluation of the viability

$\operatorname{Viability~}(\%)=100 \cdot\left(\frac{\left(A_{S}-A_{B}\right)}{\left(A_{C}-A_{B}\right)}\right)$

$A_{S} \ldots$ absorbance of sample

$A_{B} \ldots$ absorbance of background (well without cell)

Ac... absorbance of control (the cells treated with a serum-free medium without samples)

Figure S1: Effects of 3 $\alpha$-hydroxy-5 $\beta$-cholan-24-ethylamide (1) on cell viability determined by the NR assay after $24 \mathrm{~h}$ treatment. The values represent the mean \pm SD of three sets of independent experiments.

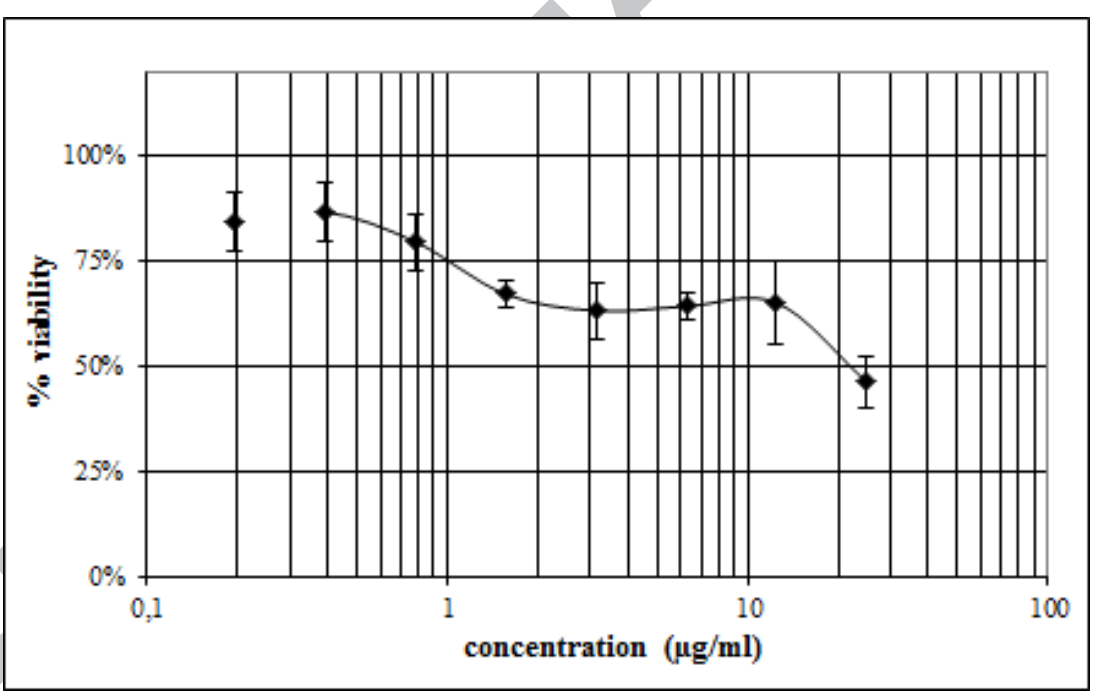


Figure S2: Effects of $3 \alpha, 12 \alpha$-dihydroxy-5 $\beta$-cholan-24-ethylamide (2) on cell viability determined by the NR assay after $24 \mathrm{~h}$ treatment. The values represent the mean \pm SD of three sets of independent experiments.

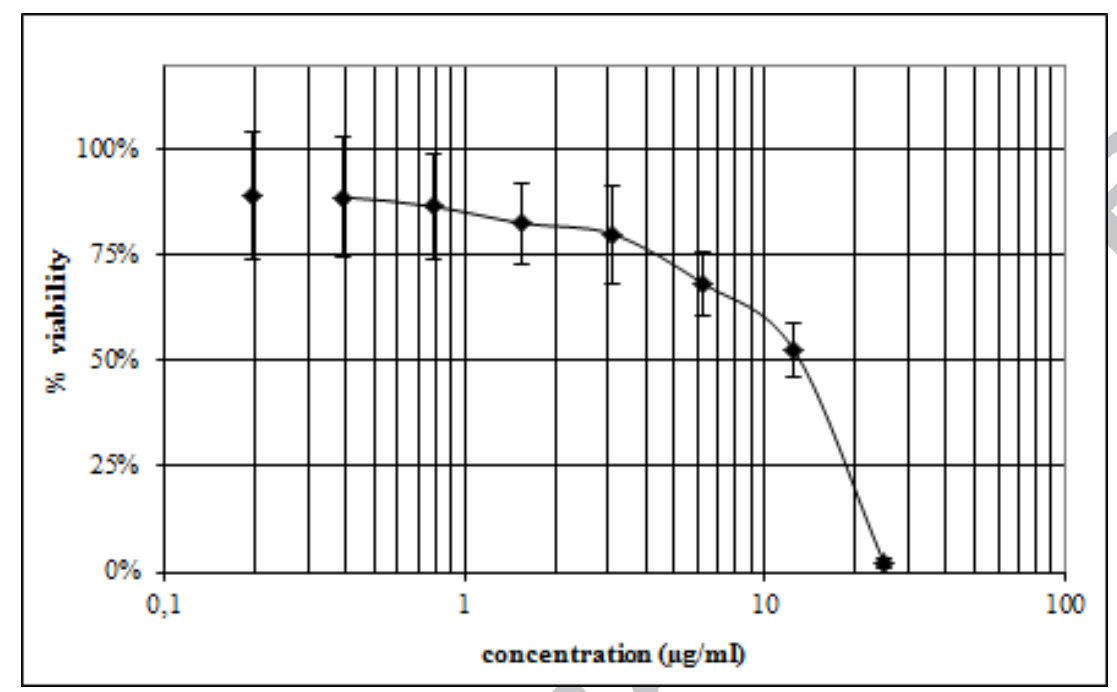

Figure S3: Effects of $3 \alpha, 7 \alpha, 12 \alpha$-trihydroxy-5 $\beta$-cholan-24-ethylamide (3) on cell viability determined by the NR assay after $24 \mathrm{~h}$ treatment. The values represent the mean \pm SD of three sets of independent experiments.

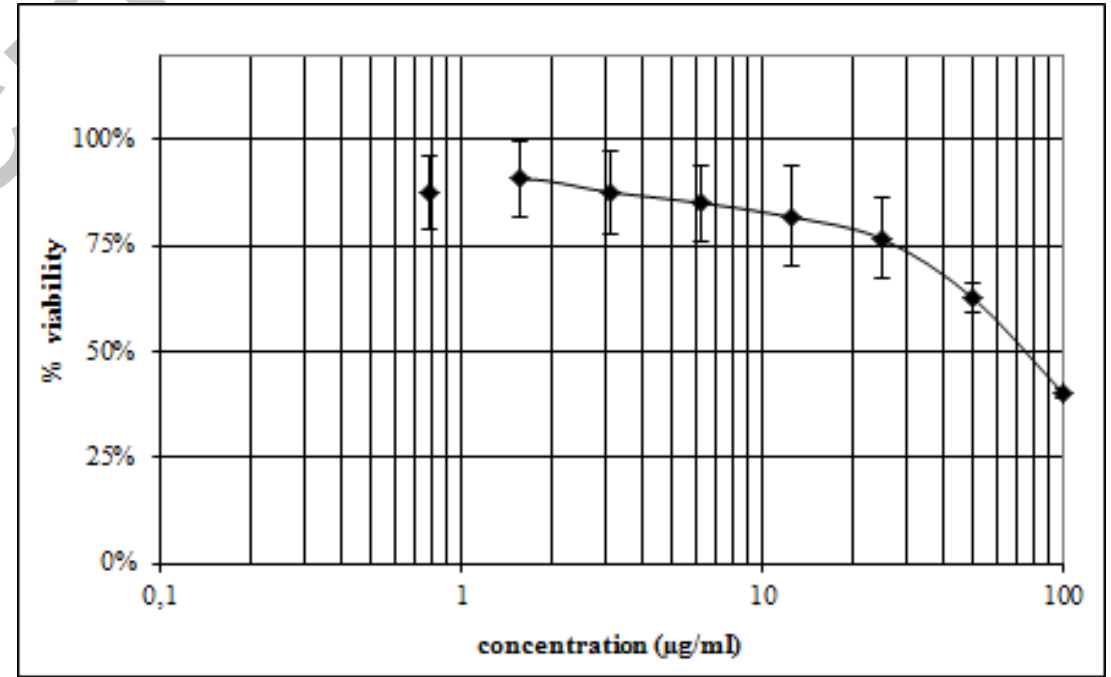


Figure S4: Effects of 3,7,12-trioxo-5 $\beta$-cholan-24-ethylamide (4) on cell viability determined by the NR assay after $24 \mathrm{~h}$ treatment. The values represent the mean \pm SD of three sets of independent experiments.

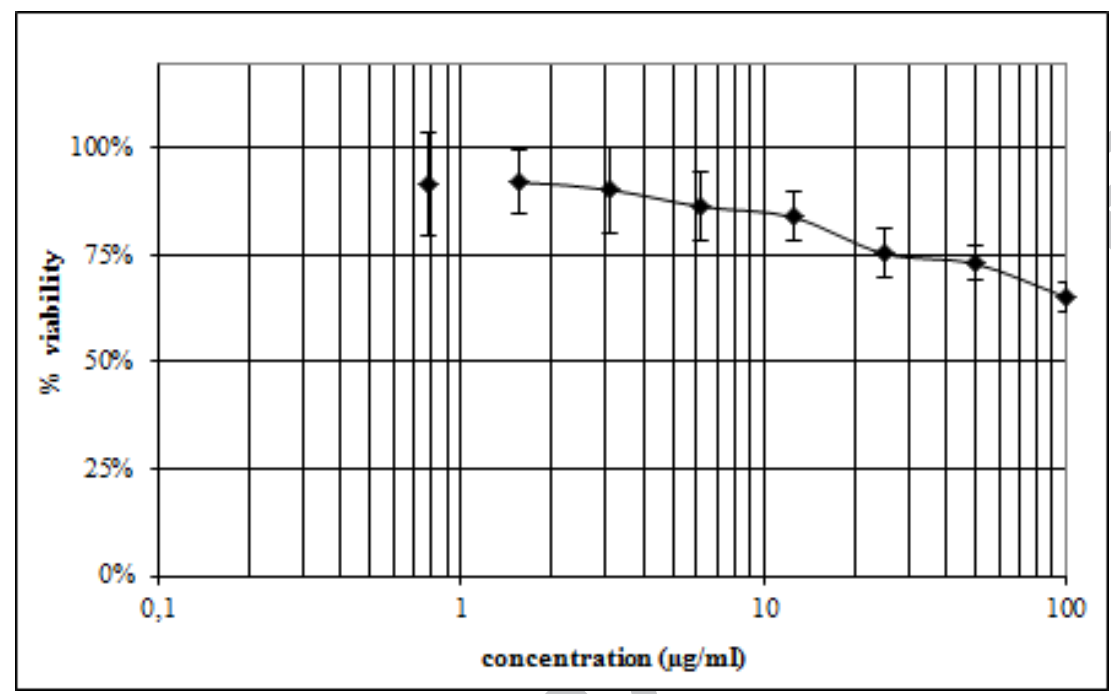


Biocompatible Hydrogelators Based on Bile Acid Ethyl Amides

Riikka Kuosmanen, Rakesh Puttreddy, Roosa-Maria Willman, Ilkka Äijäläinen, Adéla Galandáková, Jitka Ulrichová, Hannu Salo, Kari Rissanen, and Elina Sievänen*
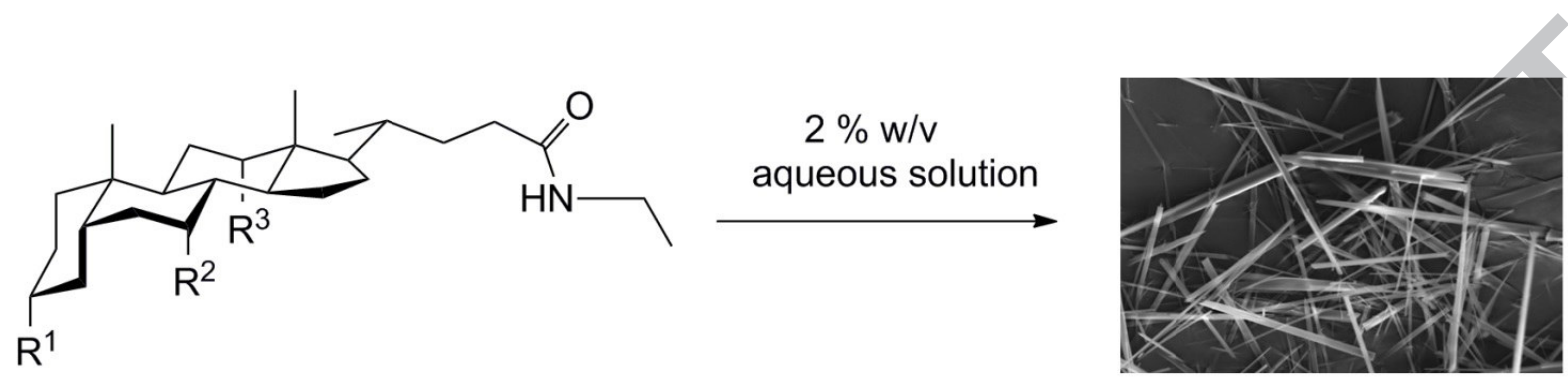


\section{Biocompatible Hydrogelators Based on Bile Acid Ethyl Amides}

Riikka Kuosmanen ${ }^{1}$, Rakesh Puttreddy ${ }^{1}$, Roosa-Maria Willman ${ }^{1}$, Ilkka Äijäläinen ${ }^{1}$, Adéla

Galandáková $^{2}$, Jitka Ulrichová ${ }^{2}$, Hannu Salo ${ }^{1}$, Kari Rissanen ${ }^{1}$, and Elina Sievänen ${ }^{1 *}$

${ }^{1}$ University of Jyvaskyla, Department of Chemistry, P.O.Box 35, FI-40014 University of Jyvaskyla, Finland

${ }^{2}$ Palacký University in Olomouc, Department of Medical Chemistry and Biochemistry, Hnévotínská 3, CZ-775 15 Olomouc, Czech Republic

\section{Highlights}

- Four new bile acid ethyl amide derivatives were synthesized and characterized in detail.

- Several gel systems, including for the first time bile acid amide derived hydrogels, were formed.

- The properties of the gels were investigated, and the toxicity of the compounds determined.

- The XRD-derived packing patterns may reveal the gel state assembly of the molecules.

- The biocompatibility of these and other bile acid-based hydrogels may be used in biomedicine. 